\title{
Application of Engineered Sorbent Barriers Summary of Laboratory Data for FY 1988
}
H. D. Freeman
E. O. Jones

September 1989

Prepared for the U.S. Department of Energy under Contract DE-AC06-76RLO 1830

Pacific Northwest Laboratory Operated for the U.S. Department of Energy by Battelle Memorial Institute 


\title{
DISCLAIMER
}

This program was prepared as an account of work sponsored by an agency of the United States Government. Neither the United States Government nor any agency thereof, nor Battelle Memorial Institute, nor any or their employees, makes any warranty, expressed or implied, or assumes any legal liability or responsibility for the accuracy, completeness, or usefulness of any information, apparatus, product, or process disclosed, or represents that its use would not infringe privately owned rights. Reference herein to any specific commercial product, process, or service by trade name, trademark, manufacturer, or otherwise, does not necessarily constitute or imply its endorsement, recommendation, or favoring by the United States Government of any agency thereof, or Battelle Memorial Institute. The views and opinions of authors expressed herein do not necessarily state or reflect those of the United States Government or any agency thereof.

\author{
PACIFIC NORTHWEST LABORATORY \\ operated by \\ BATTELLE MEMORIAL INSTITUTE \\ for the \\ UNITED STATES DEPARTMENT OF ENERGY \\ under Contract DE-AC06-76RLO 1830
}

Printed in the United States of America

Available to DOE and DOE contractors from the

Office of Scientific and Technical Intormation, P.O. Box 62, Oak Ridge, TN 37831;

prices available from (615) 576-8401. FTS 626-8401.

Available to the public from the National Technical intormation Service,

U.S. Depariment of Commerce, 5285 Port Royal Rd., Springfield, VA 22161

NTIS Price Codes, Microfiche A01

\begin{tabular}{|c|c|}
\hline \multicolumn{2}{|c|}{ Printed Copy } \\
\hline Pages & $\begin{array}{l}\text { Price } \\
\text { Codes }\end{array}$ \\
\hline$\overline{001-025}$ & $\overline{\mathrm{A} 02}$ \\
\hline $026-050$ & $\mathrm{~A} 03$ \\
\hline $051-075$ & A04 \\
\hline $076-100$ & A05 \\
\hline $101-125$ & 406 \\
\hline 126.150 & $\mathrm{~A} 07$ \\
\hline 151.175 & $\mathrm{~A} 08$ \\
\hline $176-200$ & A09 \\
\hline $201-225$ & $\mathrm{~A} 10$ \\
\hline $226-250$ & A11 \\
\hline $251-275$ & $\mathrm{~A} 12$ \\
\hline $276-300$ & A13 \\
\hline
\end{tabular}


PNL -6997

UC -512

APPLICATION OF ENGINEERED SORBENT BARRIERS SUMMARY OF LABORATORY DATA FOR FY 1988

H. D. Freeman

E. 0 . Jones

September 1989

Prepared for

the U.S. Department of Energy

under Contract DE-ACO6-76RLO 1830

Pacific Northwest Laboratory

Richland, Washington 99352 


\section{SUMMARY}

Laboratory studies were conducted in FY 1988 by Pacific Northwest Laboratory to determine the effect of contact time, pH, solution to solid ratio, and particle size on the performance of a number of materials in adsorbing radioactive cobalt, strontium, and cesium. The laboratory studies were conducted to provide background information useful in designing an engineered sorbent barrier, which restricts the migration of radionuclides from low-leve] waste sites. Understanding how the variables affect the adsorption of ions on the sorbent materials is the key to estimating the performance of sorbent barriers under a variety of conditions.

The scope of the studies was limited to three radionuclides and four sorbent materials, but the general approach can be used to evaluate other radionuclides and conditions. The sorbent materials evaluated in this study included clinoptilolite, activated carbon, bentonite clay, and Savannah River soil. The clinoptilolite and activated carbon were identified in previous studies as the most cost-effective materials for sorption of the three radionuclides under consideration. The bentonite clay was evaluated as a component of the barrier that could be used to modify the permeability of the barrier system. The Savannah River soil was used to represent soil from a humid site.

The laboratory studies showed that for the materials being evaluated, adsorption kinetics are not very fast, which can impact the proper design of both batch and flowthrough column tests. For the same materials, the initial $\mathrm{pH}$ of the leachate did not significantly affect the distribution coefficient $\left(K_{d}\right)$ above a $\mathrm{pH}$ of 1 . The natural buffering capacity of the sorbent materials was the primary reason for this insensitivity to $\mathrm{pH}$. The solution to solid ratio used in the studies affected the measured $K_{d} s$ by up to a factor of 7. Decreasing the particle size did not have an important effect on the adsorption rate of the materiats tested. 


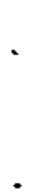




\section{CONTENTS}

SUMMARY. ..................... $i \ldots i$

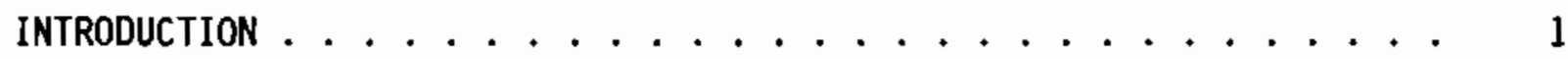

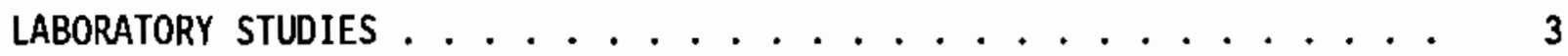

DESCRIPTION OF SORBENT MATERIALS. .............. 3

BATCH CONTACT TESTS .......................... 4

Test Procedures. . . . . . . . . . . . 5

Results.................. 6

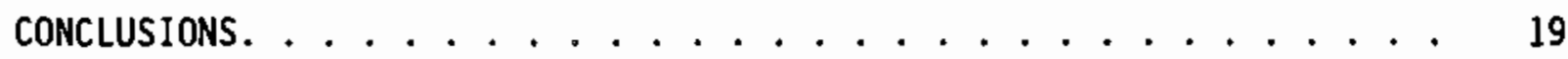

REFERENCES ...................... 21

APPENDIX - SUMMARY OF BATCH CONTACT DATA . .......... A.1 


\section{FIGURES}

1 Effect of Contact Time on the Distribution Coefficients for -5 Mesh Clinoptilolite. .............. 8

2 Effect of Contact Time on the Distribution Coefficients for -5 Mesh +35 Mesh Clinoptilolite........... 8

3 Effect of Contact Time on the Distribution Coefficients for Activated Carbon................ 9

4 Effect of Contact Time on the Distribution Coefficients for Granular Bentonite Clay. . . . . . . . . . . . 9

5 Effect of Contact Time on the Distribution Coefficients for Powdered Bentonite Clay. .............. 10

6 Effect of $\mathrm{pH}$ on the Distribution Coefficients for

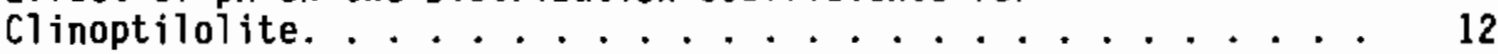

7 Effect of $\mathrm{pH}$ on the Distribution Coefficients for Activated Carbon. . . . . . . . . . . . . . . 12

8 Effect of pH on the Distribution Coefficients for Bentonite

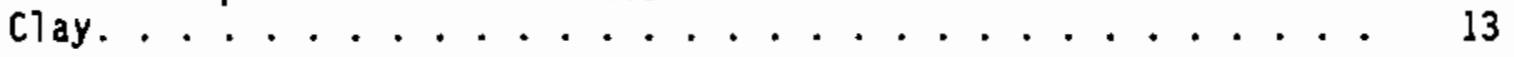

9 Effect of pH on the Distribution Coefficients for Savannah River Soil. .................. 13

10 Effect of Solution:Solid Ratio on the Distribution Coefficients for -5 Mesh Clinoptitolite. ............. 14

11 Effect of Solution:Solid Ratio on the Cobalt Distribution Coefficient for Activated Carbon. . . . . . . . . . . . 14

12 Effect of Solution:Solid Ratio on the Cesium Distribution Coefficient for Savannah River Soil ............ 15

13 Effect of Particle Size on the Distribution Coefficient and Rate of Adsorption for Clinoptilolite .......... 16

14 Effect of Particle Size on the Cobalt Distribution Coefficient and Rate of Adsorption for Activated Carbon ..........

\section{$\underline{\text { TABLE }}$}

1 Results of 1988 Benchmark Tests and Comparison with 1986 Data. . . 
INTRODUCTION

The Engineered Sorbent Barrier (ESB) technology was developed by Pacific Northwest Laboratory (PNL) ${ }^{(a)}$ as part of the Low-Level Waste Management Program, sponsored by the U.S. Department of Energy (DOE). During the program, a number of sorbent materials were evaluated and laboratory studies conducted to develop an effective method to 1 imit radionuclide migration from low-level waste (LLW) sites (Freeman, Mitchell, and Buelt 1986; Jones and Freeman 1988). The studies showed that applying an ESB to a particular site must take into account specific site conditions.

An ESB is created by lining a trench or surrounding a vault with sorptive material such as activated carbon or natural zeolites. With the barrier in place, infiltrating water can pass through the bottom of the trench while any radionuclides leached from the waste are adsorbed by the barrier material. The sorbent barrier can be designed to retard the migration of radionuclides such as ${ }^{90} \mathrm{Sr},{ }^{60} \mathrm{Co}$, and ${ }^{137} \mathrm{Cs}$ long enough to allow decay to a safe level.

Designing an ESB to remain effective for several hundred years requires that the relationship of variables such as $\mathrm{pH}$, competing ions, and adsorption kinetics be understood in terms of adsorption of ions on the sorbent materials. A number of batch contact tests were conducted in this study to determine these relationships. Some of the results were used as examples in a separate report, "Technology Assessment Guide for Application of Engineered Sorbent Barriers to Low-Level Waste Sites" (Freeman, Jones, and Depner 1989). The data presented in the following text summarizes the laboratory studies conducted in FY 1988.

(a) Operated for the U.S. Department of Energy by Battelle Memorial Institute under Contract DE-AC06-76RLO 1830. 


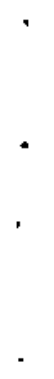




\section{LABORATORY STUDIES}

The laboratory testing in FY 1988 focused on the adsorption behavior of clinoptilolite, bentonite clay, and activated carbon with a simulated LLW leachate. Specifically, the studies concentrated on batch contact testing to determine the distribution coefficients $\left(K_{d}\right)$ of the three sorbent materials. The $K_{d}$ is the ratio of the ion concentration in the solids to the concentration in the interstitial water at equilibrium:

$$
K_{d}=c_{s} / c_{s 01}
$$

Consequently, the $K_{d}$ can be used to measure the effectiveness of a material in adsorbing a particular ion from solution. The $K_{d}$ can also be determined using flowthrough column tests; however, the batch contact tests showed that results from column tests could not readily be obtained within the study period.

The three materials used in the study were chosen because adsorption performance was good and the cost was relatively low (Freeman, Mitchel1, and Buelt 1986). A limited number of tests were also performed on Savannah River soil to represent a typical soil from a humid climate. The simulated leachate used in the majority of the tests contained the standard composition of $1 \mu \mathrm{Ci} / \mathrm{L}$ each of ${ }^{85} \mathrm{Sr},{ }^{60} \mathrm{Co}$, and ${ }^{137} \mathrm{Cs} ; 100 \mathrm{ppm}$ each of $\mathrm{Ca}$, $\mathrm{Na}$, and $\mathrm{Mg}$ ions; 1 ppm of EDTA as a complexing agent; with an adjusted solution pH of 5 . The nonradioactive ions were added to simulate the ions expected to be present from leaching of the natural soil and waste forms. EDTA was added to simulate the presence of a complexant that mobilizes ${ }^{60} \mathrm{Co}$, normally not a very mobile ion. In some of the tests, the standard conditions were altered to allow the effect of variables to be assessed. A summary of the data obtained in these tests is presented in the appendix.

\section{DESCRIPTION OF SORBENT MATERIALS}

The materials used for the FY 1988 studies were similar to materials used in the tests reported in Freeman, Mitche11, and Buelt (1986). The clinoptilolite, a natural zeolite, was obtained from Teague Minerals in 
Adrian, Oregon. Materials from two different deposits, designated as the $\mathrm{CH}$ and $X Y$ deposit, were tested aithough only one set of tests was performed on the $X Y$ deposit. Because material from the $X Y$ deposit was found to be less effective in adsorbing the radionuclides of interest and more costly than the CH deposit, the remainder of the tests were performed on two different size fractions of the $\mathrm{CH}$ deposit. The first size fraction was a -5 mesh material, which represented material as produced by the crusher (sample ID prefix of CH1). This material contained a significant fraction of fines. The second size distribution contained material in the size range -5 mesh +35 mesh (sample ID prefix of $\mathrm{CH} 2$ ). This distribution represented a relatively coarse material with a more reproducible size range that could provide the basis for material specifications. Because of its lower cost, the -5 mesh material was used more extensively.

Bentonite, a swelling clay, was tested because it may be used to adjust the permeability of the barrier mixture to optimize residence time of the leachate in the sorbent layer. The bentonite clay used for these tests was al so obtained from Teague Minerals. A granular material (sample ID prefix of $B E 1$ ) and a fine material (sample ID prefix of BE2) were tested.

The activated carbon, which is used to adsorb the organic complexed species that can be found in LLW leachate, was obtained from the Calgon corporation. The material, as received, was sized as $-6+16$ mesh.

\section{BATCH CONTACT TESTS}

Test conditions were varied in the batch contact tests to provide information useful in estimating the long-term performance of sorbent barriers. The variations in the tests included:

- length of batch contact time - to determine the rate of adsorption

- solution $\mathrm{pH}$ and solution:solid ratio - to determine how they affect adsorption

- adsorbent particle size - to alter the rate of adsorption.

This section gives the procedures used for the tests, the equation used for data analysis, and the results of the tests. 


\section{Test Procedures}

Before the tests, the solids were dried at $110^{\circ} \mathrm{C}$ for $24 \mathrm{~h}$ and allowed to cool to room temperature. If the material was not used immediately, it was sealed in an airtight container or bag. Next, a batch of the simulated leachate was prepared and adjusted to the appropriate $\mathrm{pH}(\mathrm{pH}$ expected in the trench.

Duplicate samples were prepared for each test by weighing the desired amount of solid and placing it in a $250-\mathrm{mL}$ polyethylene wide-mouth bottle. Two hundred milliliters of simulated leachate were added to the bottle, and the bottle was sealed. One sample was prepared as a blank without sorbent material in case a particular radionuclide tended to adsorb on the surface of the container.

The bottles were gently agitated with a shaker platform for various times ranging from $1 / 2$ to $256 \mathrm{~h}$. The solutions were then filtered with a $0.45 \mathrm{\mu m}$ filter to remove the solids. Twenty milliliters of the filtrate from each sample were analyzed for all ions of interest. A sample of the simulated leachate used in each series of tests was also analyzed. Most of the samples were only analyzed for radionuclide content using gamma spectroscopy. In some instances, nonradioactive ions were evaluated with inductively coupled plasma analysis.

The $K_{d}$ was calculated for each radionuclide from the gamma spectroscopy analyses using the following equation:

$$
K_{d}=\frac{(L v)(\text { Initia })-\text { Fina })}{(\text { Sw) }(\text { Fina })}
$$

where $K_{d}=$ distribution coefficient, $\mathrm{mL} / \mathrm{g}$

$$
\begin{aligned}
& L v=\text { liquid volume, } \mathrm{mL} \\
& S w=\text { weight of solids, } g
\end{aligned}
$$




\section{Initial = initial counts in simulated leachate before contacting with solids}

Final = final counts in solution after contacting with solids.

\section{Results}

The test results inciude data from benchmark tests and data on the effect of contact time, leachate solution $\mathrm{pH}$, solution to solid ratio, and particle size.

\section{Benchmark Tests}

Benchmark tests were performed to compare the effectiveness of materials used for this study against materials tested in earlier studies. Previously tested materials included clinoptilolite from the $\mathrm{CH}$ deposit and activated carbon. In addition, two different size fractions of two new materials, clinoptilolite from the $X Y$ deposit and bentonite clay, were included to determine their relative effectiveness. The test conditions were similar to tests run in 1986 (Freeman, Mitche11, and Buelt 1986). The simulated leachate for the benchmark tests contained the standard composition described in this report. This leachate composition differed from the 1986 study in that it contained $100 \mathrm{ppm} \mathrm{Mg}$ and $\mathrm{Na}$ instead of $1000 \mathrm{ppm}$. The materials were contacted for $72 \mathrm{~h}$ to match the contact time of earlier studies. The results of the 1986 and 1988 measurements are compared in Table 1.

IABLE 1. Results of 1988 Benchmark Tests and Comparison with 1986 Data Distribution Coefficient, $\mathrm{mL} / \mathrm{g}$

\begin{tabular}{|c|c|c|c|c|c|}
\hline \multicolumn{3}{|c|}{1988} & \multicolumn{3}{|c|}{1986} \\
\hline${ }^{85} \mathrm{Sr}$ & ${ }^{137} \mathrm{Cs}_{\mathrm{S}}$ & ${ }^{60} \mathrm{Co}$ & ${ }^{85} \mathrm{Sr}$ & ${ }^{137} \mathrm{Cs}$ & ${ }^{60} \mathrm{Co}_{0}$ \\
\hline 1090 & 3860 & 0.5 & NA & NA & NA \\
\hline 1100 & 3340 & -0.3 & 165 & 1130 & 66.4 \\
\hline 553 & 4900 & -1.2 & NA & NA & NA \\
\hline 564 & 5370 & 1.2 & NA & NA & NA \\
\hline 13.0 & 25.1 & 681 & 27.1 & 28.5 & 611 \\
\hline 67.7 & 2080 & 2.0 & NA & NA & NA \\
\hline 72.8 & 2770 & 3.0 & NA & NA & NA \\
\hline
\end{tabular}


The results of the $\mathrm{CH}$ deposit $\mathrm{clinoptilolite}$ do not compare well between the 1988 and 1986 data. The material received in 1988 appears to be more effective in adsorbing $\mathrm{Sr}$ and $\mathrm{C} s$ but less effective in sorbing $\mathrm{C}_{0}$. This difference could be due to the higher $\mathrm{Na}$ and $\mathrm{Mg}$ concentration in the 1986 tests or to differences in the materials within the deposit. The data for the activated carbon, on the other hand, compare very closely. The differences in the data emphasize the need for a good quality assurance program during construction of an ESB.

Table 1 also shows that the $X Y$ deposit is not as effective in adsorbing $\mathrm{Sr}$ as the less expensive $\mathrm{CH}$ deposit material. The $\mathrm{XY}$ deposit was not evaluated in any further tests. The bentonite clay has a moderate $K_{d}$ for $\mathrm{Sr}$ and a good $K_{d}$ for $C_{s}$. If bentonite is used in a barrier formulation, its adsorption effectiveness should be incorporated into the performance assessment.

\section{Effect of Contact Time}

Typically, when adsorption of ions on materials is simulated in radionuclide transport models, it is assumed that the adsorption reaction reaches equilibrium in a short time period. This assumption is probably valid for cases where the leachate moves through the solids at a slow rate. However, in laboratory flowthrough column tests, where the leachate travels through the column at relatively high velocities, the assumption of fast kinetics may lead to errors in measuring the $K_{d}$. Therefore, a series of tests were performed to investigate the effect of contact time on the sorbent material $k_{d}$. The tests were conducted using the standard simulated leachate at a 200 to 1 solution to solid ratio. The contact times included $1 / 2,1,2,4,16,72$, 120 , and $256 \mathrm{~h}$. The results of these tests are shown in Figures 1 through 5.

When plotted on a $\log -\log$ scale, most of the data follows a linear relationship. This implies that the kinetics of adsorption follow a power law relationship:

$$
K_{d}(t)=K \cdot t^{b}
$$




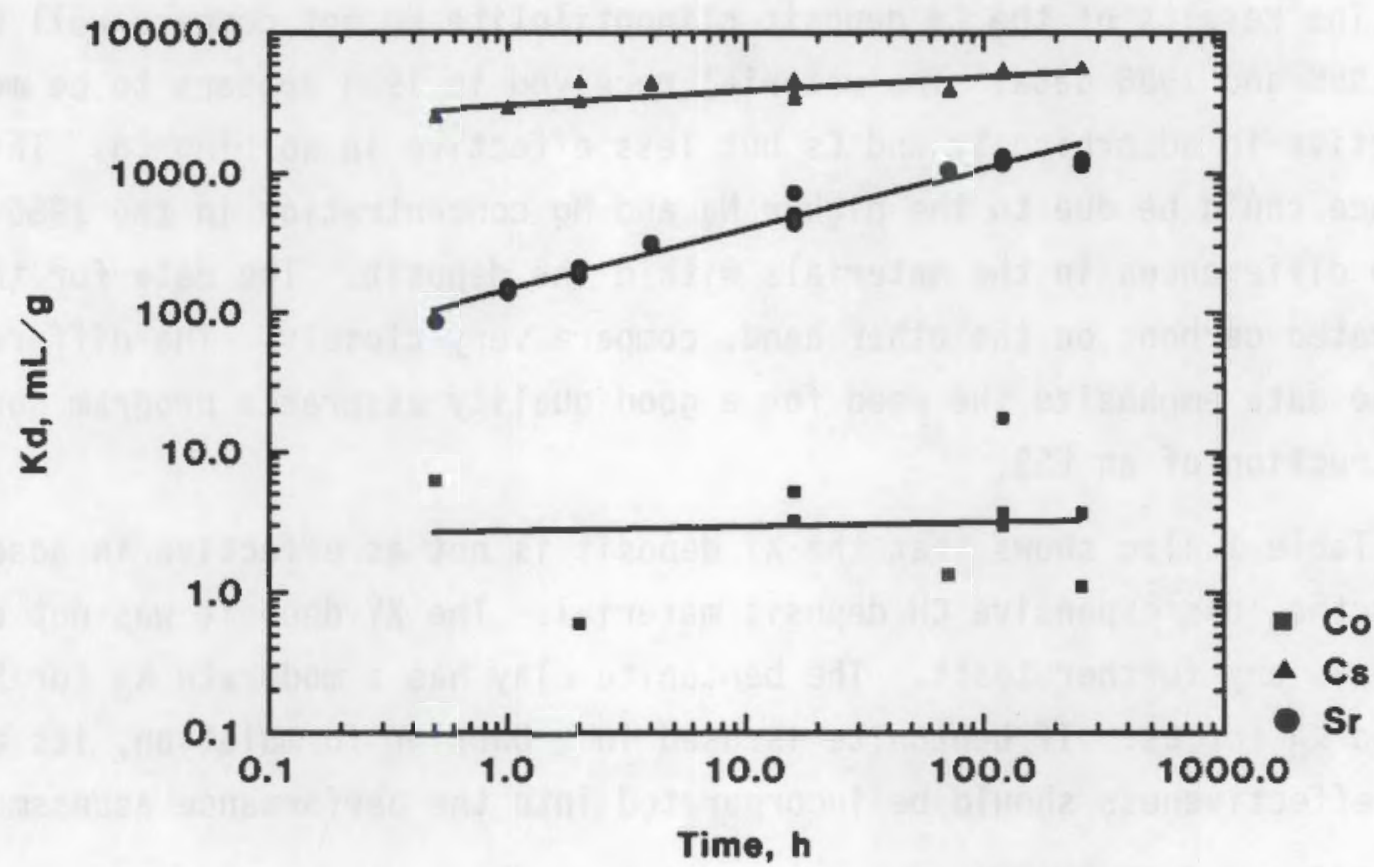

FIGURE 1. Effect of Contact Time on the Distribution Coefficients for -5 Mesh Clinoptilolite

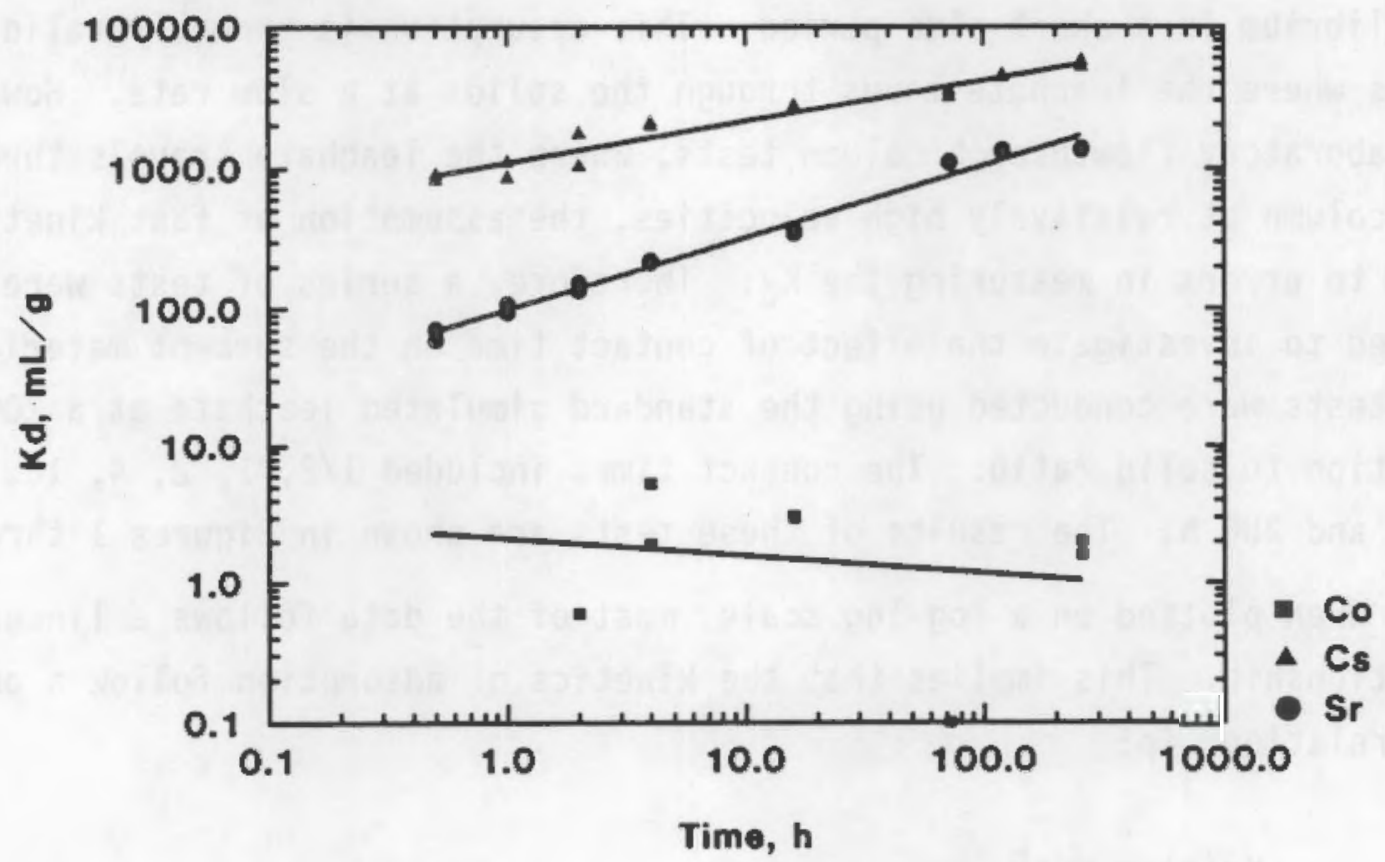

FIGURE 2. Effect of Contact Time on the Distribution Coefficients for -5 Mesh +35 Mesh Clinoptilolite 


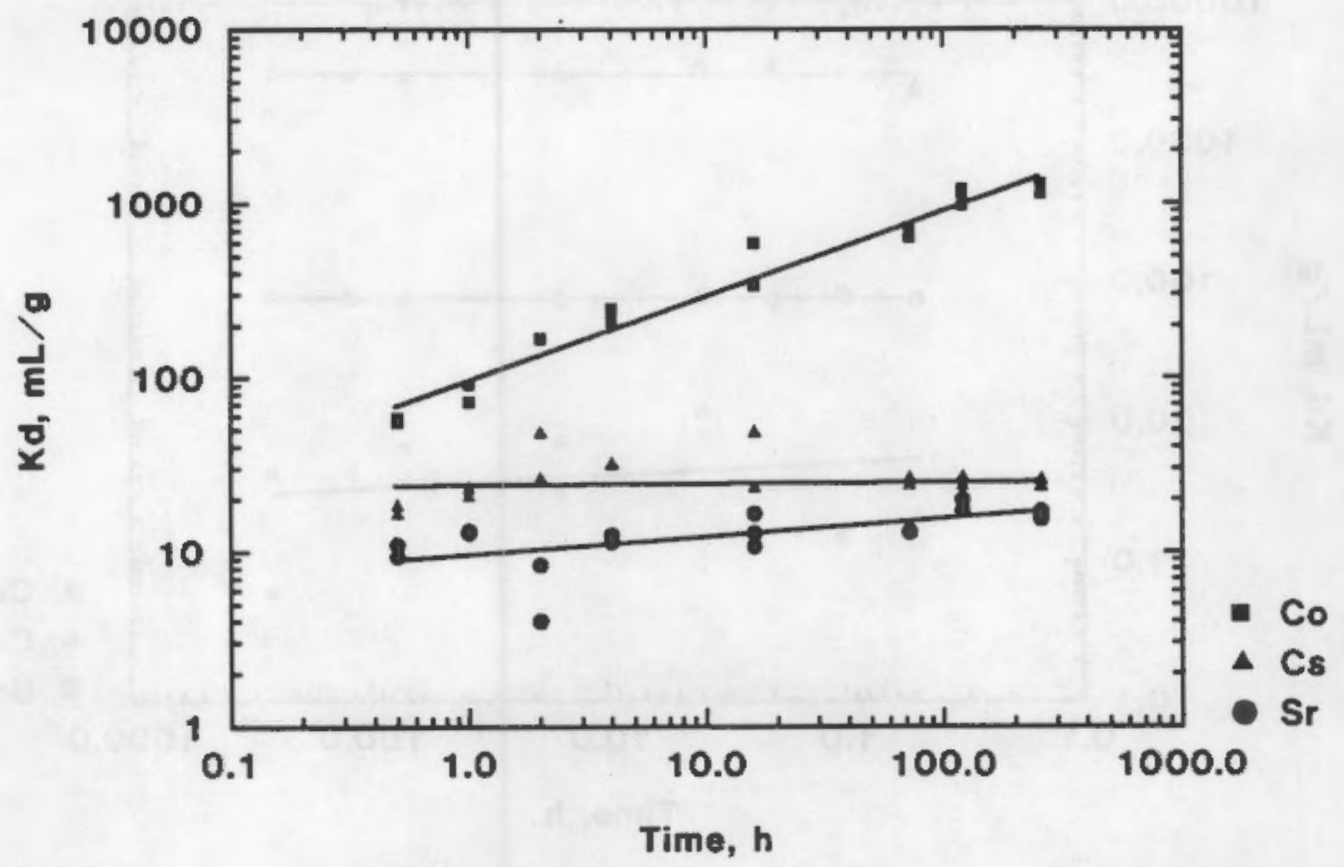

FIGURE 3. Effect of Contact Time on the Distribution Coefficients for Activated Carbon

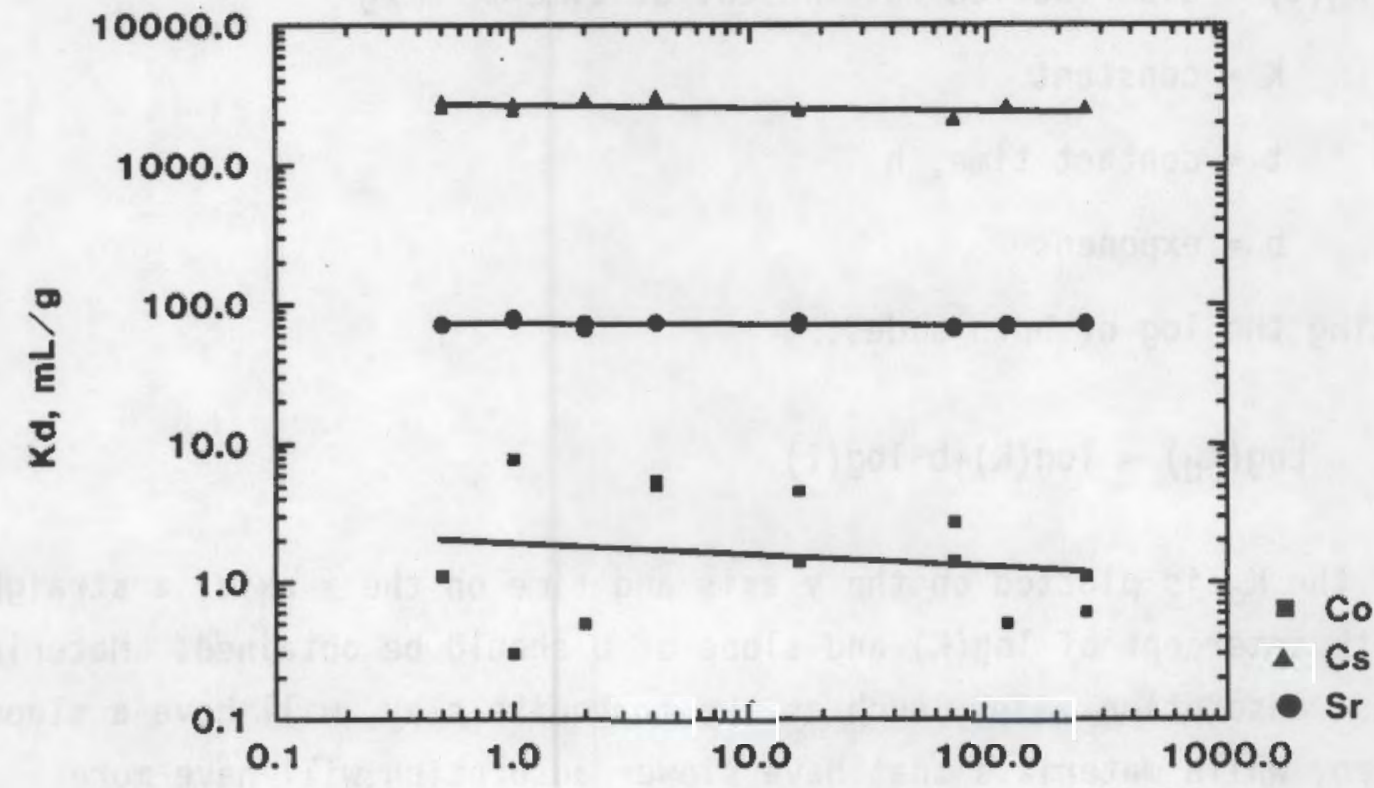

Time, h

FIGURE 4. Effect of Contact Time on the Distribution Coefficients for Granular Bentonite Clay 


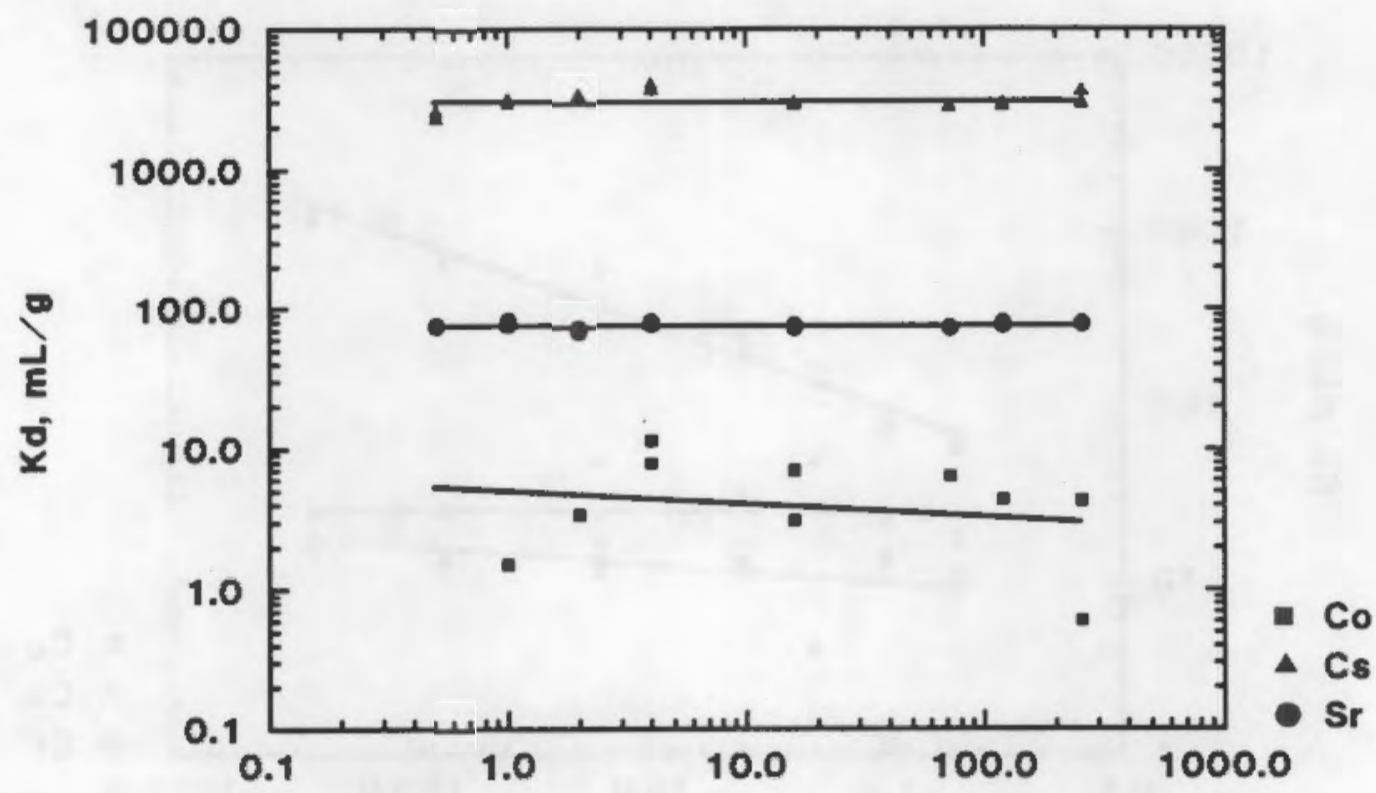

Time, h

FIGURE 5. Effect of Contact Time on the Distribution Coefficients for Powdered Bentonite Clay

where $K_{d}(t)=$ distribution coefficient at time $t, \mathrm{~mL} / \mathrm{g}$

$$
\begin{aligned}
& k=\text { constant } \\
& t=\text { contact } t \text { ime, } h \\
& b=\text { exponent }
\end{aligned}
$$

or, taking the $\log$ of both sides:

$$
\log \left(K_{d}\right)=\log (K)+b * \log (t)
$$

Thus if the $K_{d}$ is plotted on the $y$ axis and time on the $x$ axis, a straight line with intercept of $\log (K)$ and slope of $b$ should be obtained. Materials with fast adsorption rates, such as the bentonite clay, will have a slope near zero, while materials that have slower adsorption will have more positive slopes.

The data in Figures 1 through 5 show that the adsorption of radionuclides on clinoptilolite and activated carbon requires at least $120 \mathrm{~h}$ to reach equilibrium. Adsorption rates on bentonite clay, however, are much faster. 
The slow adsorption kinetics for clinoptilolite and activated carbon requires that any flowthrough column tests be run at extremely slow flow rates if equilibrium is to be obtained between the solids and leachate. This requirement would preclude the use of accelerated exposure tests designed to simulate many years of infiltration in a few weeks or months.

\section{Effect of Leachate Solution $\mathrm{pH}$}

The effectiveness of sorbent materials in adsorbing ions can be highly dependent on the $\mathrm{pH}$ of the liquid phase. In many cases the solid phase has a natural buffering capacity that minimizes the impact of changes in $\mathrm{pH}$ which may occur in the liquid phase. Because of this natural buffering capacity, the tests to determine the effect of $\mathrm{pH}$ were performed by changing the $\mathrm{pH}$ of the simulated leachate rather than by adjusting the $\mathrm{pH}$ of the solution after contacting the solids. The tests covered a pH range of 1 to 9 , the expected range for a typical humid LLW site. The tests were conducted using a solution to solid ratio of 200 to 1 with an exposure time of $120 \mathrm{~h}$.

Figures 6 through 9 show the effect of $\mathrm{pH}$ on the $\mathrm{K}_{d}$ for ${ }^{85} \mathrm{Sr},{ }^{137} \mathrm{Cs}$, and ${ }^{60} \mathrm{Co}$ on clinoptilolite, activated carbon, bentonite clay, and Savannah River soil, respectively. These figures show that the $K_{d}$ for the first three materials is not highly dependent on the initial pH of the leachate above a $\mathrm{pH}$ of 1. Although the scope of the project did not include it, the total buffering capacity of the solids should be measured to determine how long the solids will be able to buffer the leachate passing through the barrier.

\section{Effect of Solution to Solid Ratio}

Batch contact tests are generally performed at a relatively high solution to solid ratio, especially for materials with large $K_{d} s$. A number of tests were performed to determine if the solution to solid ratio has an effect on the measured $K_{d}$ of a material. The tests were performed over a solution to solid ratio of 20 to 1000 for activated carbon and clinoptilolite, and 20 to 400 for Savannah River soil. Tests were performed using the standard simulated leachate composition with an exposure time of $120 \mathrm{~h}$. Results of these tests are shown in Figures 10 through 12. 


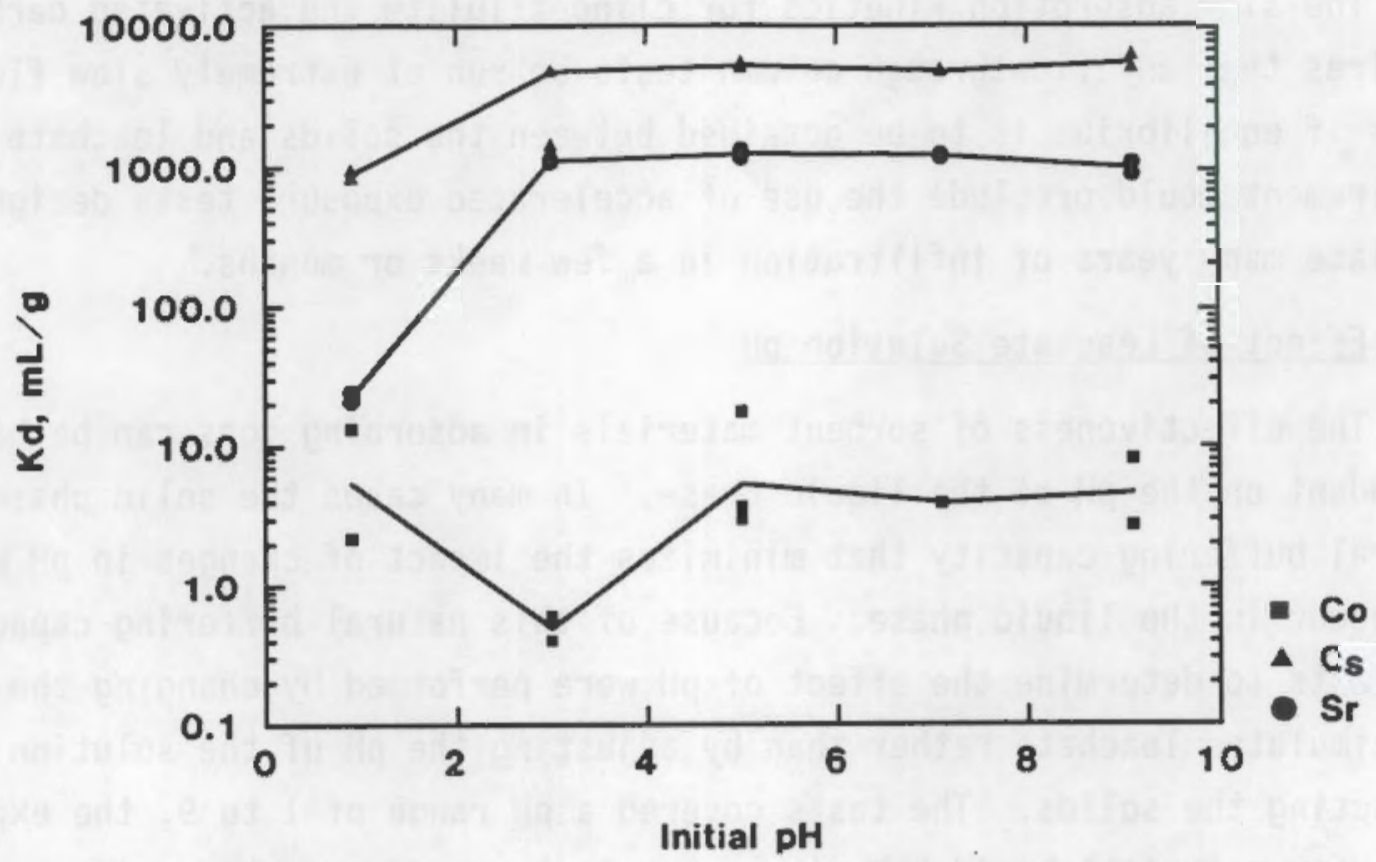

FIGURE 6. Effect of $\mathrm{pH}$ on the Distribution Coefficients for $\mathrm{Cl}$ inoptilolite

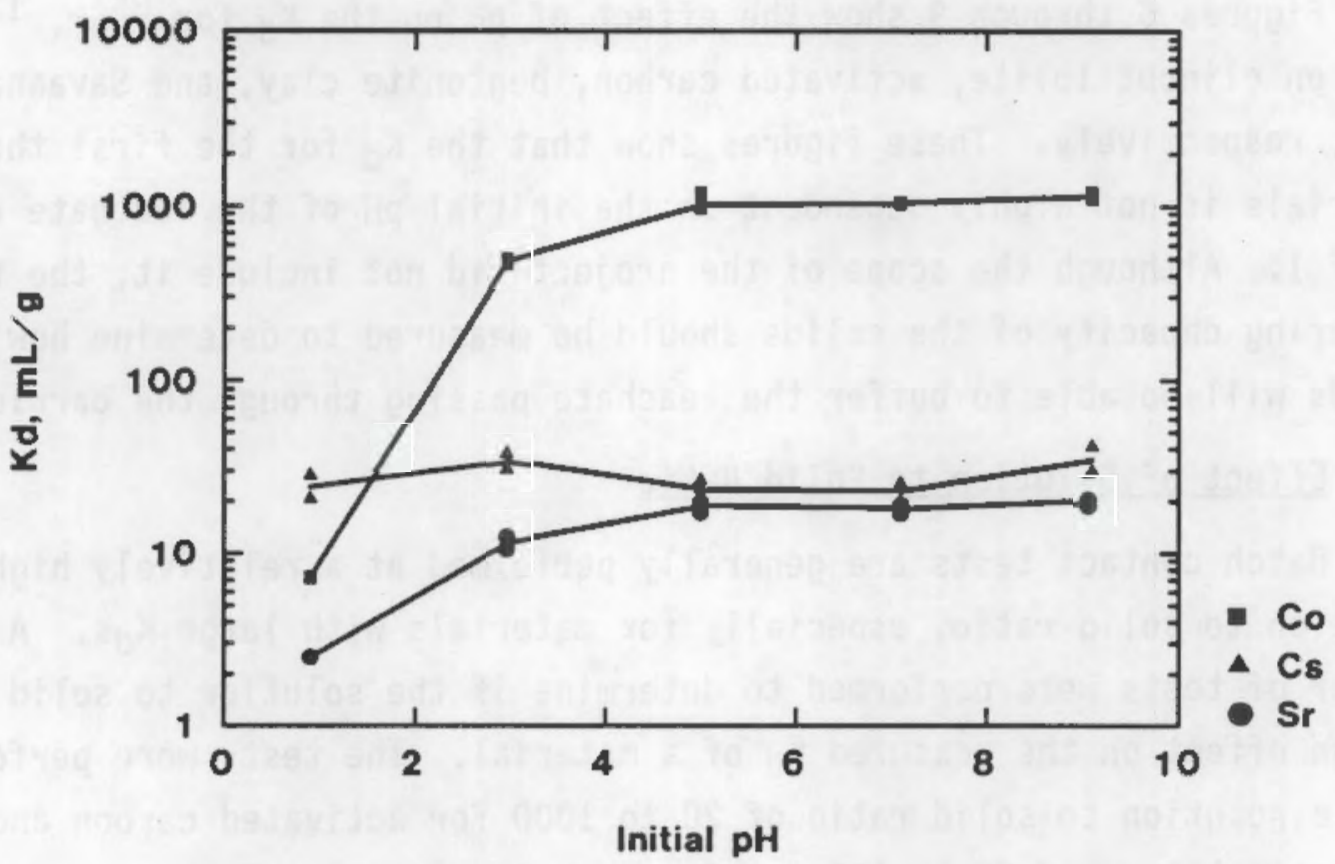

FIGURE 7. Effect of pH on the Distribution Coefficients for Activated Carbon 


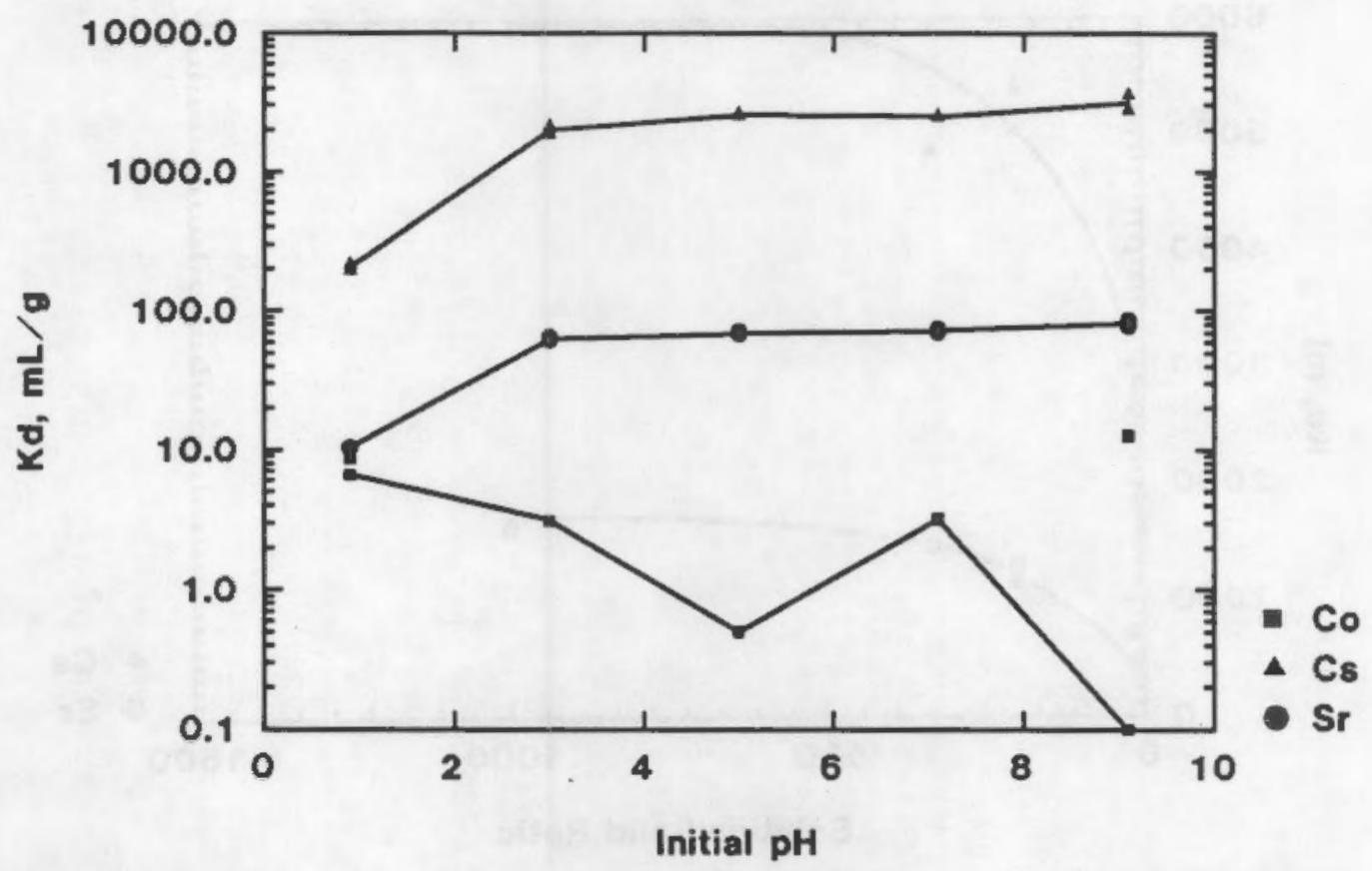

FIGURE 8. Effect of pH on the Distribution Coefficients for Bentonite Clay

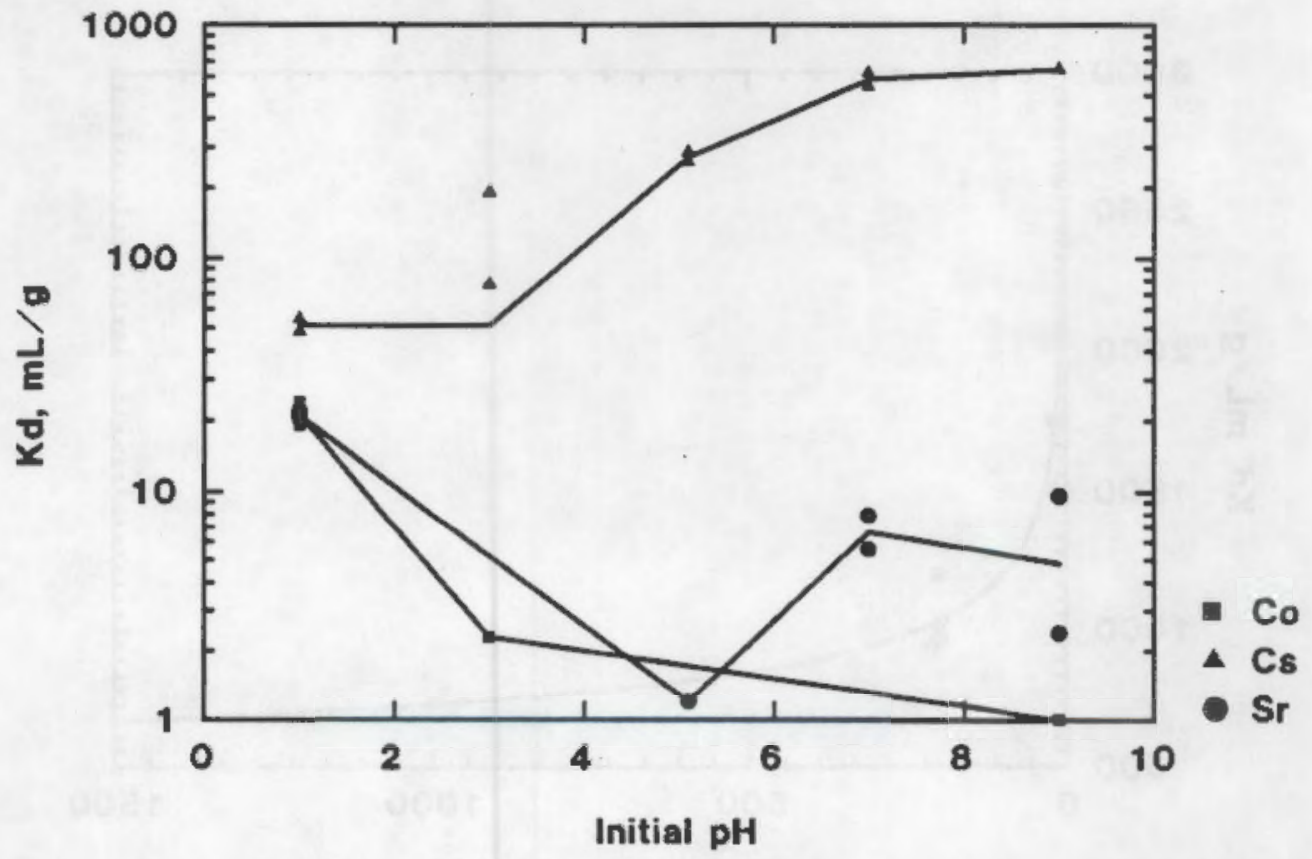

FIGURE 9. Effect of pH on the Distribution Coefficients for Savannah River Soil 


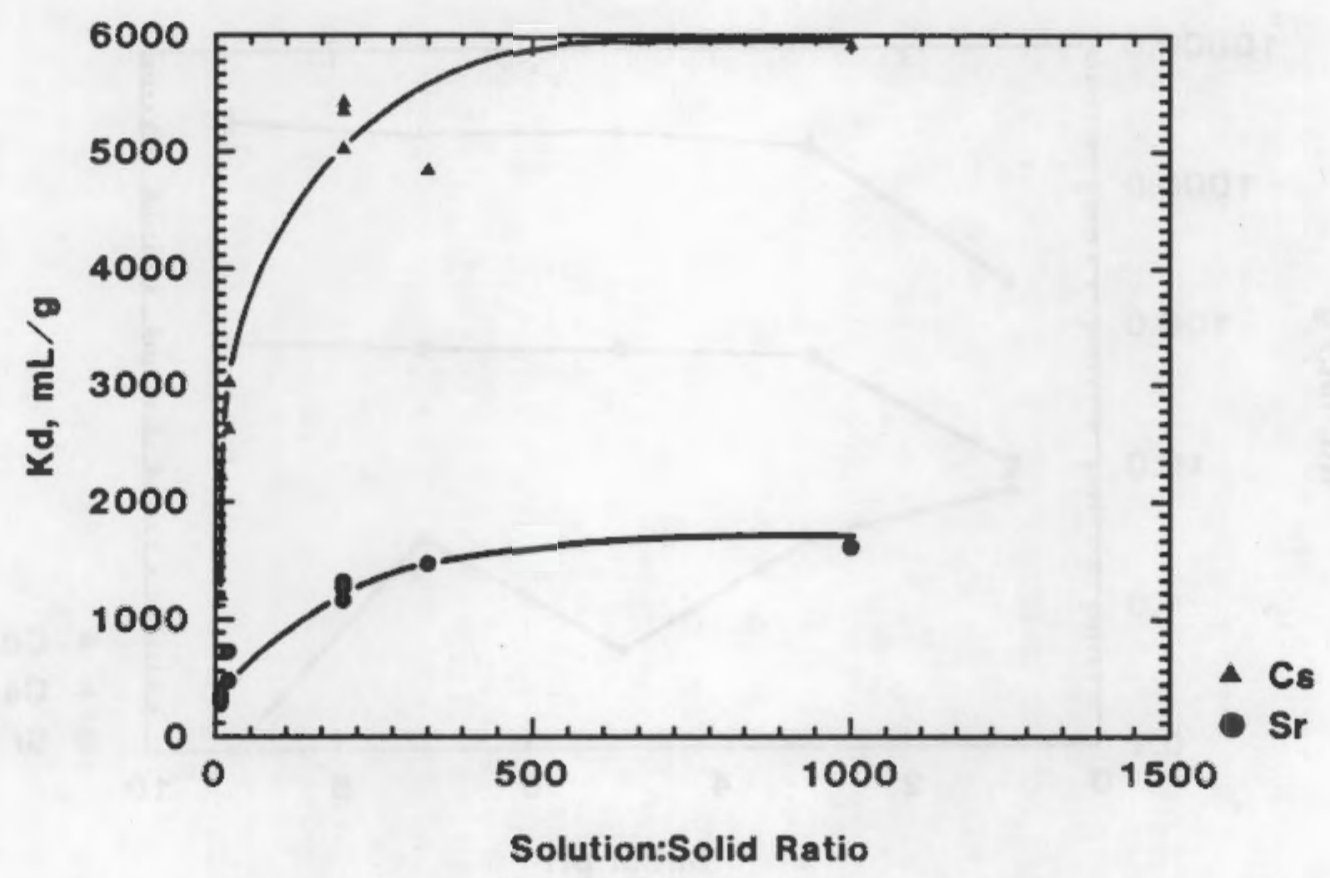

FIGURE 10. Effect of Solution:Solid Ratio on the Distribution Coefficients for -5 Mesh Clinoptilolite

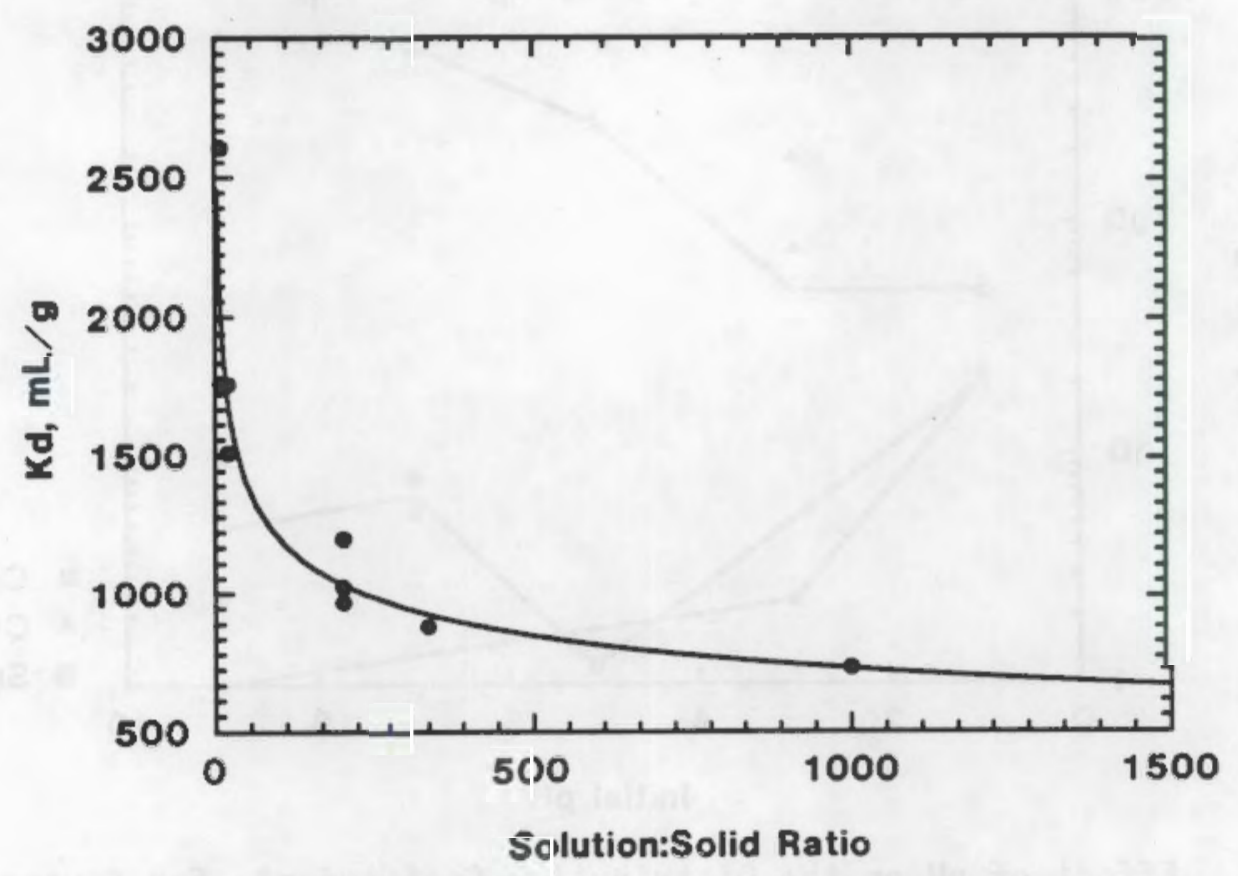

FIGURE 11. Effect of Solution:Solid Ratio on the Cobalt Distribution Coefficient for Activated Carbon 


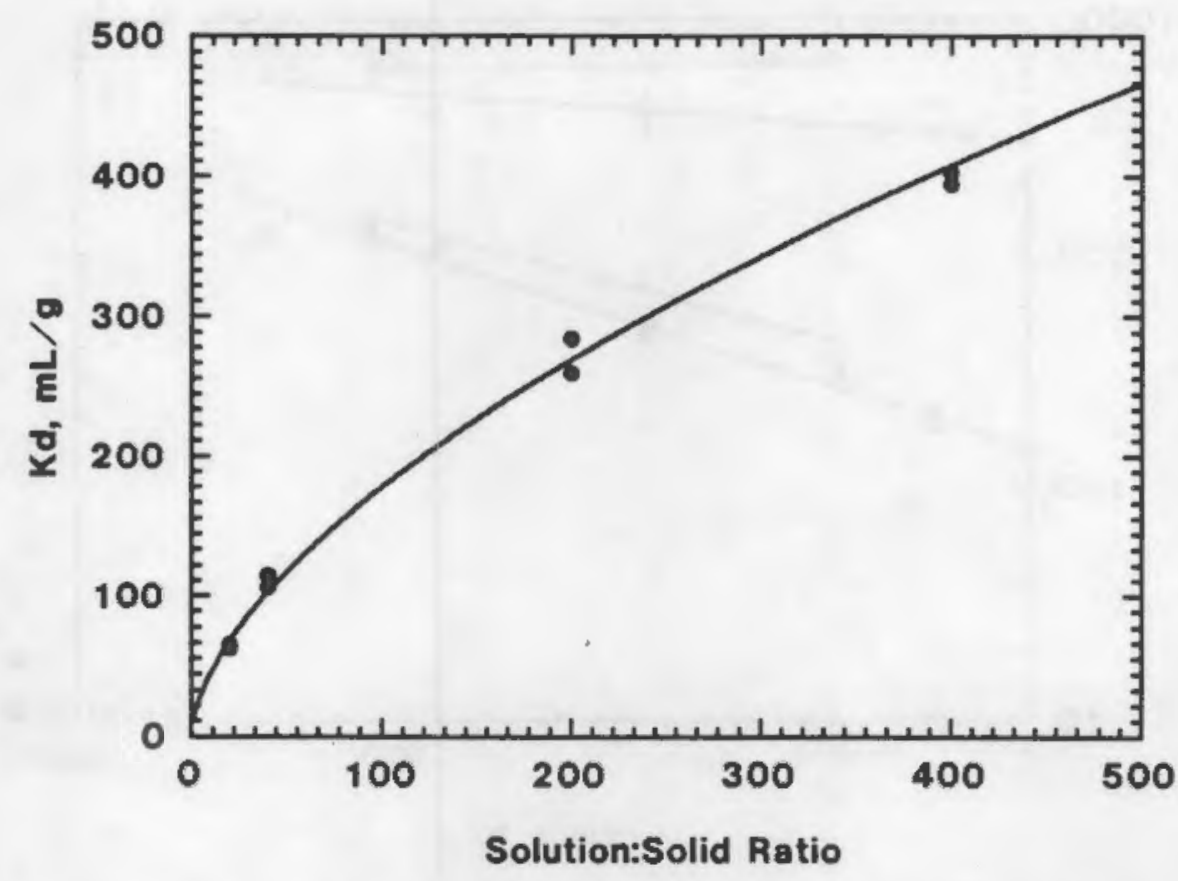

FIGURE 12. Effect of Solution:Solid Ratio on the Cesium Distribution Coefficient for Savannah River Soil

\section{Effect of Particle Size}

One technique for accelerating column tests, used by manufacturers of activated carbon, is to use very small particles of adsorbent. The fine particles reduce the path length for interparticle diffusion. The rate of adsorption is increased if the interparticle diffusion controls the overall rate of adsorption. If chemical kinetics are controlling, then reducing the particle size will not increase the adsorption rate.

Batch contact tests were completed with ground and standard-sized clinoptilolite and with ground and standard-sized activated carbon at different solution to solid ratios and contact times. Figures 13 and 14 show the effect of particle size on the rate of adsorption on clinoptilolite and activated carbon, respectively. The ground activated carbon ( -200 mesh) had a slightly faster adsorption rate than standard-sized activated carbon. The implication is that the interparticle diffusion is a controlling mechanism for adsorption of ${ }^{60} \mathrm{Co}_{0}$ onto activated carbon, although the relationship is not strong enough to imply that it is the rate-limiting step. 


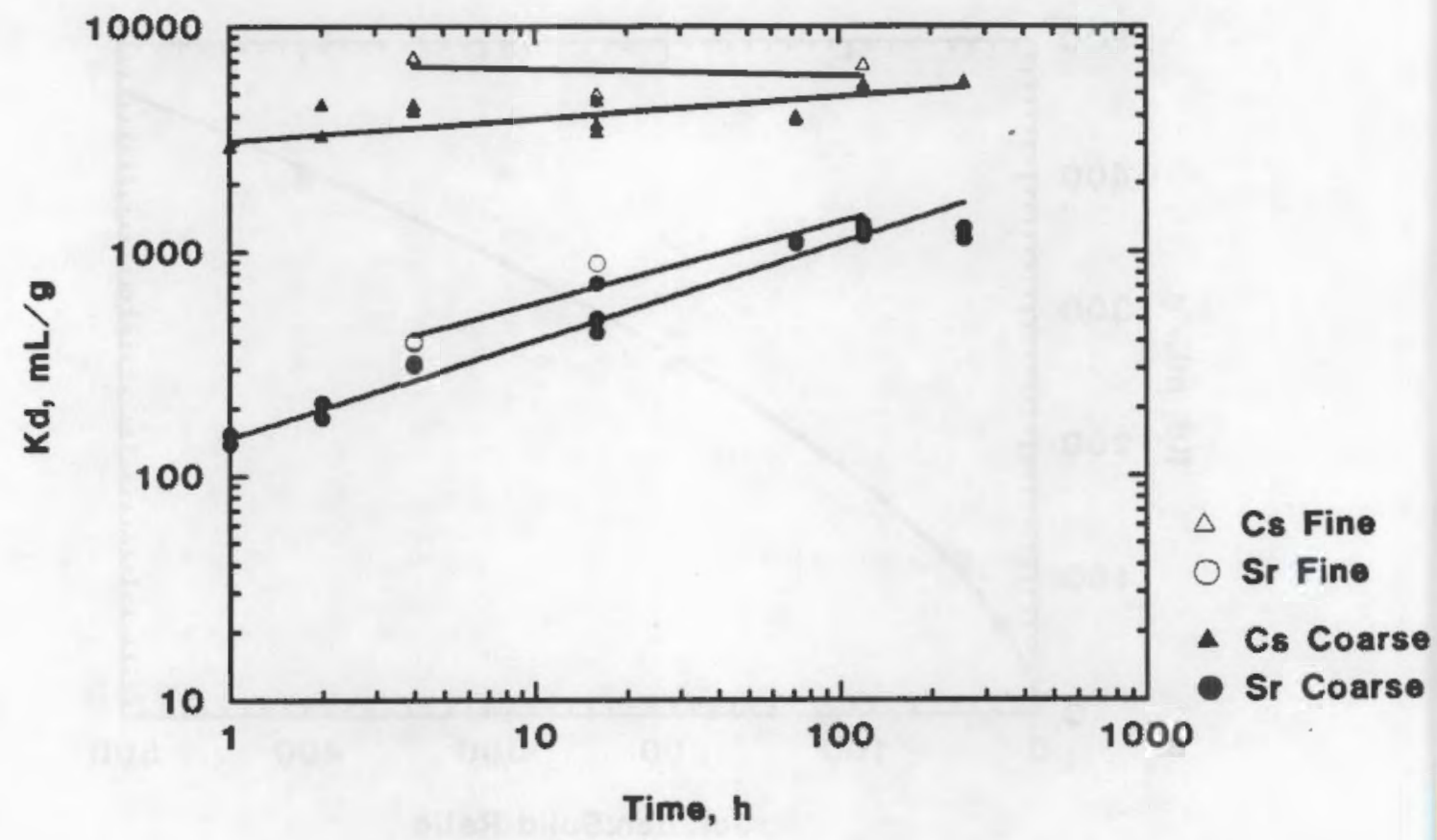

FIGURE 13. Effect of Particle Size on the Distribution Coefficient and Rate of Adsorption for Clinoptilolite

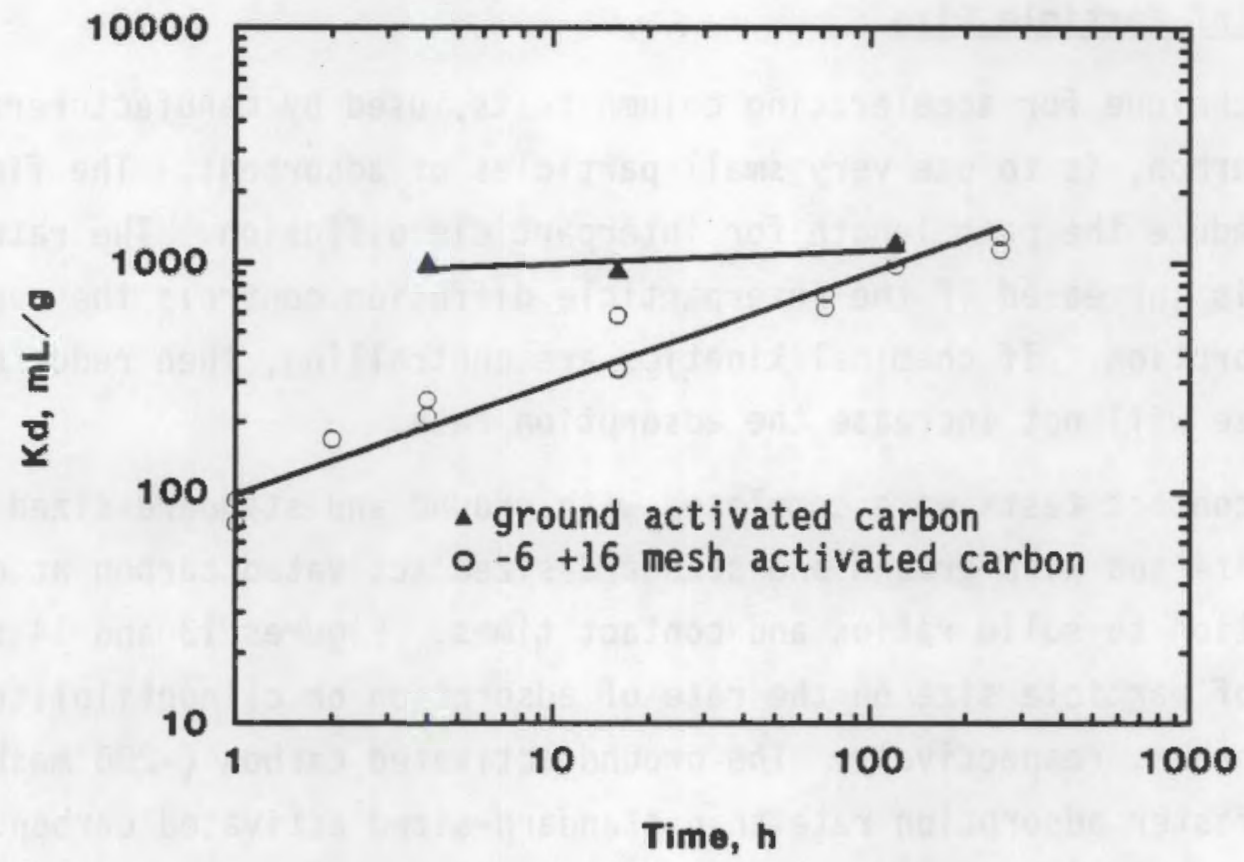

FIGURE 14. Effect of Particle Size on the Cobalt Distribution Coefficient and Rate of Adsorption for Activated Carbon 
The adsorption rate of ${ }^{85} \mathrm{Sr}$ on ground clinoptilolite $(-200$ mesh) was not altered by the particle size, an indication that the rate of chemical reactions is 7 imiting the adsorption. Possibly, the adsorption of ${ }^{85} \mathrm{Sr}$ onto clinoptilolite follows a series of faster competing ionic adsorption; the adsorption of ${ }^{85} \mathrm{Sr}$ is thermodynamically more stable but occurs at a slower kinetic rate than other competing adsorption. The increased adsorption rate for activated carbon was not high enough to recommend this technique be used for flowthrough column tests for these materials. 


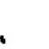




\section{CONCLUSIONS}

The results of the batch contact tests led to the following conclusions:

- Adsorption kinetics is an important parameter that should be investigated first in the sorbent material performance studies to determine the optimum contact time for the remainder of the tests.

- For the conditions under investigation in this study, pH did not have a significant impact on the $K_{d}$ above a $\mathrm{pH}$ of 1 . However, the effect of $\mathrm{pH}$ can be important in some instances and, therefore, should be included in all investigations of sorbent material effectiveness.

- The solution to solid ratio used in the batch contact tests affected the measured distribution coefficients by up to a factor of 7 .

- Decreasing particle size did not increase the rate of adsorption of strontium on clinoptilolite and only had a moderate effect for adsorption of cobalt on activated carbon. 


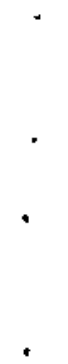




\section{REFERENCES}

Freeman, H. D., E. O. Jones, and J. P. Depner. 1989. Technology Assessment Guide for Application of Engineered Sorbent Barriers to Low-Level Waste Sites. PNL-6882, Pacific Northwest Laboratory, Richland, Washington.

Freeman, H. D., S. J. Mitchell, and J. L. Buelt. 1986. Engineered Sorbent Barriers for Low-Level Waste Disposal. PNL-6051, Pacific Northwest Laboratory, Richland, Washington.

Jones, E. O., and H. D. Freeman. 198B. "Design of Engineered Sorbent Barriers." In Proceedings of the 10th Annual DOE Low-Level Waste Management Conference. CoNF-880839, August 30-September 1, 1988, Denver, Colorado. 



\section{APPENDIX}

SUMMARY OF BATCH CONTACT DATA 


\section{APPENDIX}

\section{SUMMARY OF BATCH CONTACT DATA}

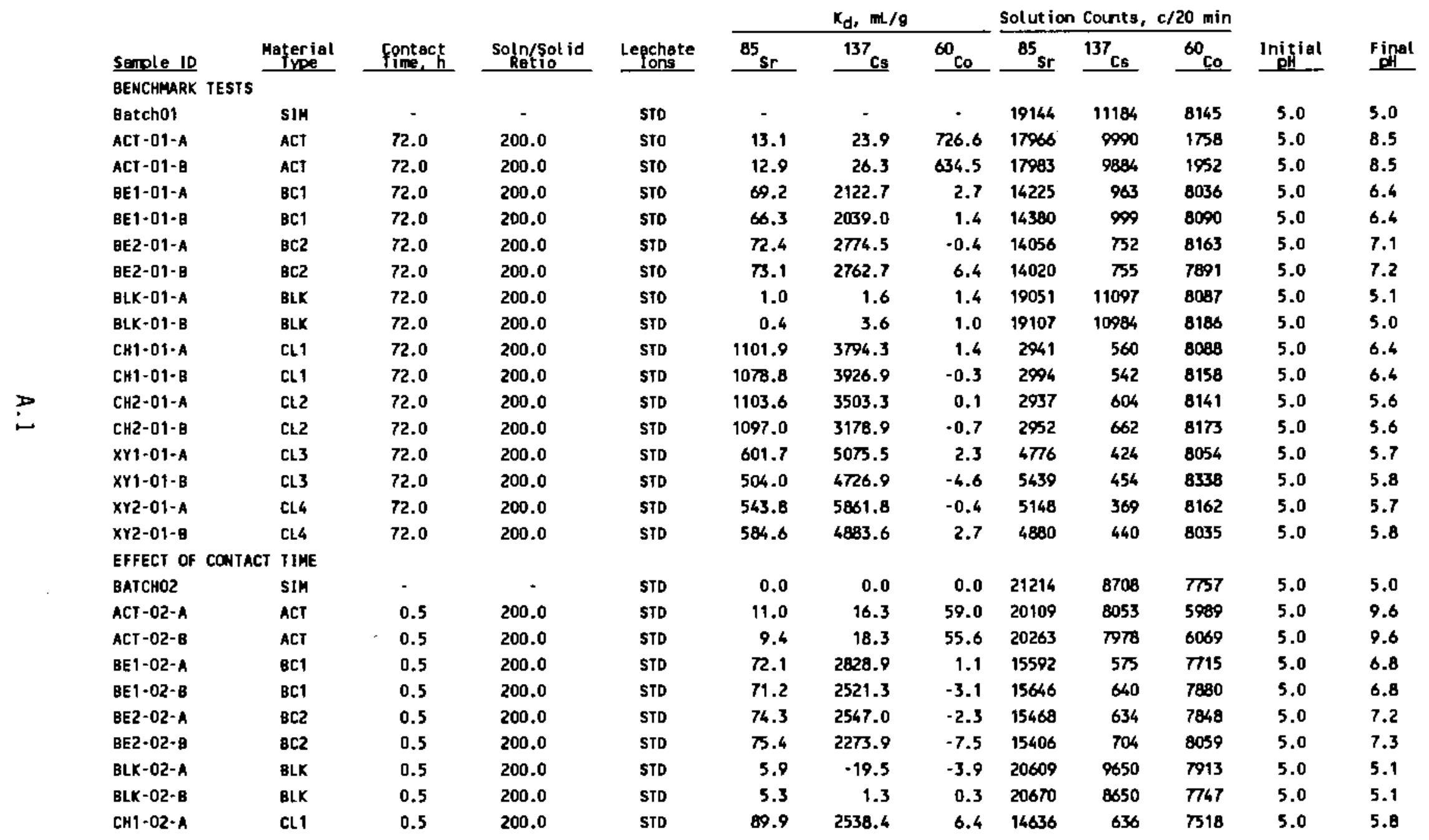


Appendix (contd)

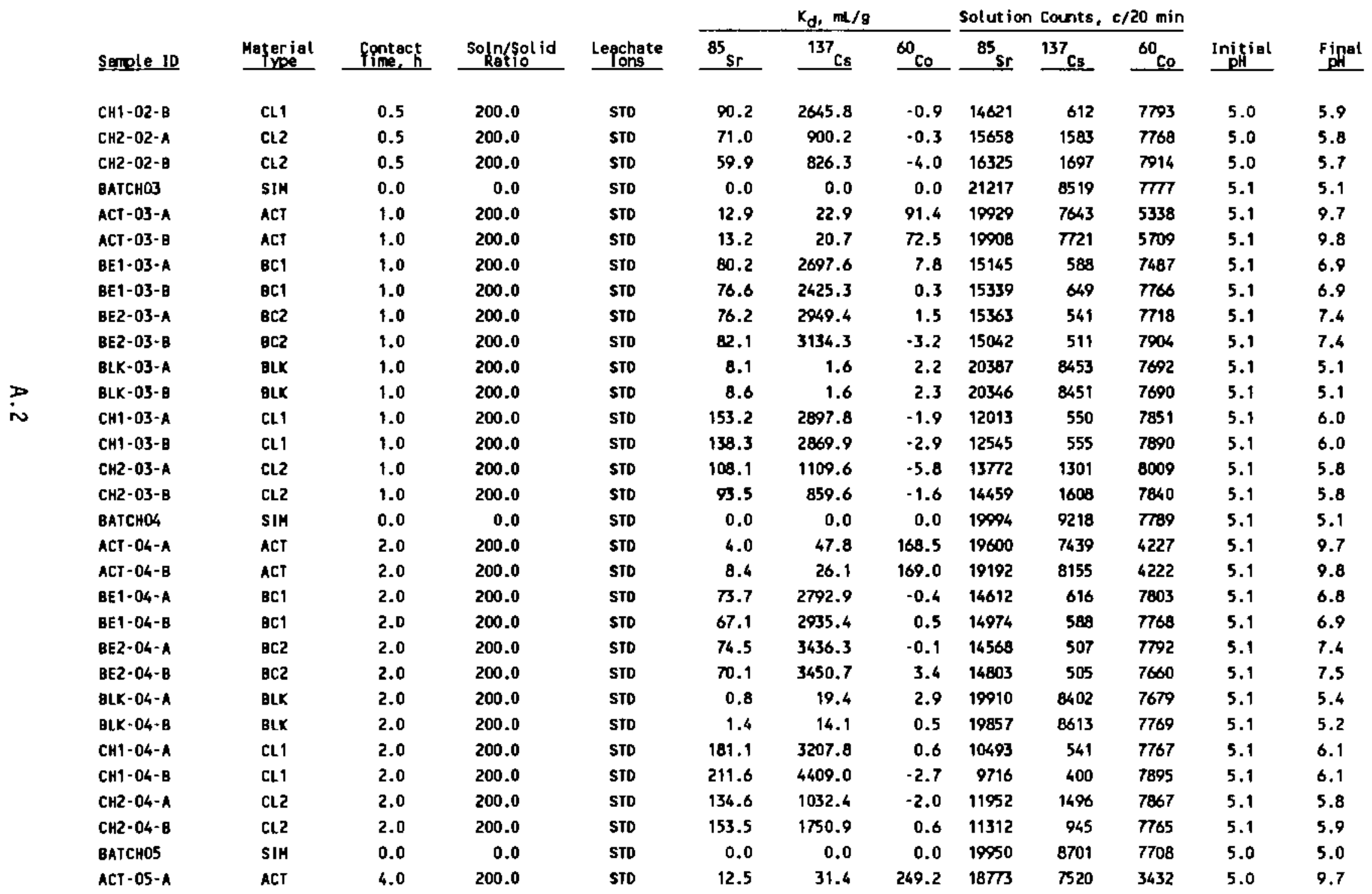


Appendix (contd)

\begin{tabular}{|c|c|c|c|c|c|c|c|c|c|c|c|c|}
\hline \multirow[b]{2}{*}{ Sanple ID } & \multirow[b]{2}{*}{$\begin{array}{c}\text { Maţerial } \\
\text { type } \\
\end{array}$} & \multirow[b]{2}{*}{$\begin{array}{l}\text { Contact } \\
\text { fine, }\end{array}$} & \multirow[b]{2}{*}{$\underset{\text { Soln }}{\text { Sol }_{0}}$} & \multirow[b]{2}{*}{$\begin{array}{c}\text { Lepchate } \\
\text { Jons }\end{array}$} & \multicolumn{3}{|c|}{$K_{d}, m L / g$} & \multicolumn{2}{|c|}{ Solution Counts, } & \multirow{2}{*}{$\frac{/ 20 \text { min }}{60}$} & \multirow[b]{2}{*}{ lnitrial } & \multirow[b]{2}{*}{ Fiph } \\
\hline & & & & & ${ }^{85} 5 r$ & ${ }^{137}{ }_{\mathrm{Cg}}$ & $t_{C_{0}}$ & ${ }^{85} \mathrm{sr}$ & ${ }^{137} \mathrm{Cs}$ & & & \\
\hline ACT-05-B & ACT & 4.0 & 200.0 & STD & 11.4 & 31.9 & 211.0 & 18876 & $\pi 505$ & $3 \longdiv { 5 1 }$ & 5.0 & 9.7 \\
\hline BE 1-05-A & BC1 & 4.0 & 200.0 & STO & 73.6 & 2759.5 & 5.5 & 14586 & 588 & $\longdiv { 5 0 2 }$ & 5.0 & 6.8 \\
\hline BE1-05-B & $\operatorname{Bc1}$ & 4.0 & 200.0 & STD & 74.0 & 3040.6 & 5.1 & 14563 & 537 & $历 18$ & 5.0 & 6.8 \\
\hline BE2-05-A & ec2 & 4.0 & 200.0 & STD & 80.4 & 4013.6 & 7.9 & 14232 & 413 & 7415 & 5.0 & 7.5 \\
\hline BE2-05-B & $\mathrm{BC2}$ & 4.0 & 200.0 & STD & 77.3 & 3675.7 & 11.5 & 14391 & 449 & 7280 & 5.0 & 7.5 \\
\hline BLK-05-A & BLK & 4.0 & 200.0 & STD & 6.0 & 17.0 & 2.4 & 19371 & 8018 & 7615 & 5.0 & 5.1 \\
\hline BLK-05-8 & BLK & 4.0 & 200.0 & STD & 5.9 & 18.5 & -0.3 & 19378 & 7965 & $\pi 18$ & 5.0 & 5.1 \\
\hline $\mathrm{CH} 1-05-\mathrm{A}$ & CL1 & 4.0 & 200.0 & STo & 311.9 & 4130.7 & $\cdot 2.0$ & $\pi r 94$ & 401 & $\pi / 85$ & 5.0 & 6.1 \\
\hline CH1-05-B & CL1 & 4.0 & 200.0 & STO & 310.9 & 4403.7 & -1.0 & 7674 & 378 & 7747 & 5.0 & 6.1 \\
\hline $\mathrm{CH} 2-05-\mathrm{A}$ & CL2 & 4.0 & 200.0 & Sto & 221.2 & 2065.9 & 1.9 & 0472 & 768 & 7636 & 5.0 & 5.9 \\
\hline СH2-05-B & CL2 & 4.0 & 200.0 & STO & 213.0 & 1986.2 & 5.3 & 9661 & 796 & 7511 & 5.0 & 5.0 \\
\hline ВАТСНОS & $\sin$ & 0.0 & 0.0 & STD & 0.0 & 0.0 & 0.0 & 20920 & 8440 & 7685 & 5.0 & 5.0 \\
\hline ACT-06-A & $A C T$ & 16.0 & 200.0 & STO & 16.5 & 23.1 & 343.1 & 19325 & 566 & 2830 & 5.0 & 9.4 \\
\hline АСТ-06-B & ACT & 16.0 & 200.0 & STo & 12.8 & 48.2 & 338.2 & 19659 & 6800 & 2856 & 5.0 & 9.5 \\
\hline - BE1-06-A & BC1 & 16.0 & 200.0 & STO & 70.6 & 2389.0 & 1.4 & 15461 & 652 & 7630 & 5.0 & 6.8 \\
\hline QE1-06-B & BC1 & 16.0 & 200.0 & STD & 73.6 & 2470.9 & 4.6 & 15182 & 632 & 7513 & 5.0 & 6.8 \\
\hline BE2-06-A & $\mathrm{BC2}$ & 16.0 & 200.0 & STO & 72.8 & 2943.4 & 7.0 & 15336 & 537 & 7425 & 5.0 & 7.5 \\
\hline BE2-06-B & $\mathrm{BC2}$ & 16.0 & 200.0 & STD & 76.4 & 2841.4 & 3.1 & 15140 & 555 & 569 & 5.0 & 7.5 \\
\hline BLK-06-A & BLK & 16.0 & 200.0 & sto & 4.8 & 13.3 & -2.2 & 20428 & $\pi 15$ & $m 70$ & 5.0 & 5.3 \\
\hline BLK-06-8 & BLK & 16.0 & 200.0 & STD & 3.8 & 9.5 & 1.5 & 20532 & 8057 & 7627 & 5.0 & 4.9 \\
\hline СH1-06-А & $\mathrm{CL} 1$ & 16.0 & 200.0 & STo & 500.8 & 4581.9 & 5.2 & 5970 & 353 & 7490 & 5.0 & 6.1 \\
\hline СН1-06-日 & $\mathrm{CLI}$ & 16.0 & 200.0 & STD & 434.4 & 3601.8 & -2.0 & 6595 & 444 & 7763 & 5,0 & 6.0 \\
\hline CH2-06-A & CL2 & 16.0 & 200.0 & STO & 362.8 & 2745.9 & 3.0 & 7434 & 573 & 7570 & 5.0 & 5.9 \\
\hline CH2-06-8 & $\mathrm{CL} 2$ & 16.0 & 200.0 & sto & 344.1 & 2576.3 & 3.1 & 7690 & 608 & 7568 & 5.0 & 6.0 \\
\hline ВАТСНО7 & SIM & 0.0 & 0.0 & sto & 0.0 & 0.0 & 0.0 & 19684 & 7970 & 7442 & 5.0 & 5.0 \\
\hline$A C T-07-A$ & $\mathrm{ACT}$ & 120.0 & 200.0 & STO & 19.6 & 23.7 & 1023.0 & 17929 & 7127 & 1217 & 5.0 & 8.5 \\
\hline ACT $-07-B$ & $\mathrm{ACT}$ & 120.0 & 200.0 & STO & 17.3 & 26.6 & 966.5 & 18146 & 7034 & 1276 & 5.0 & 8.7 \\
\hline BE1-07-A & $\operatorname{act}$ & 120.0 & 200.0 & sto & 69.0 & 2543.6 & 0.5 & 14635 & 581 & 7423 & 5.0 & 6.8 \\
\hline BE1-07-B & ec1 & 120.0 & 200.0 & sto & 71.4 & 2601.4 & -0.8 & 14508 & 569 & 7473 & 5.0 & 6.8 \\
\hline BE2-07-A & BC2 & 120.0 & 200.0 & STo & 76.1 & 2830.4 & 4.4 & 14259 & 526 & 7282 & 5.0 & 7.4 \\
\hline BE2-07-B & $\mathrm{BC2}$ & 120.0 & 200.0 & sto & 79.7 & 2901.2 & -3.3 & 14077 & 514 & 7567 & 5.0 & 7.4 \\
\hline
\end{tabular}


Appendix (contd)

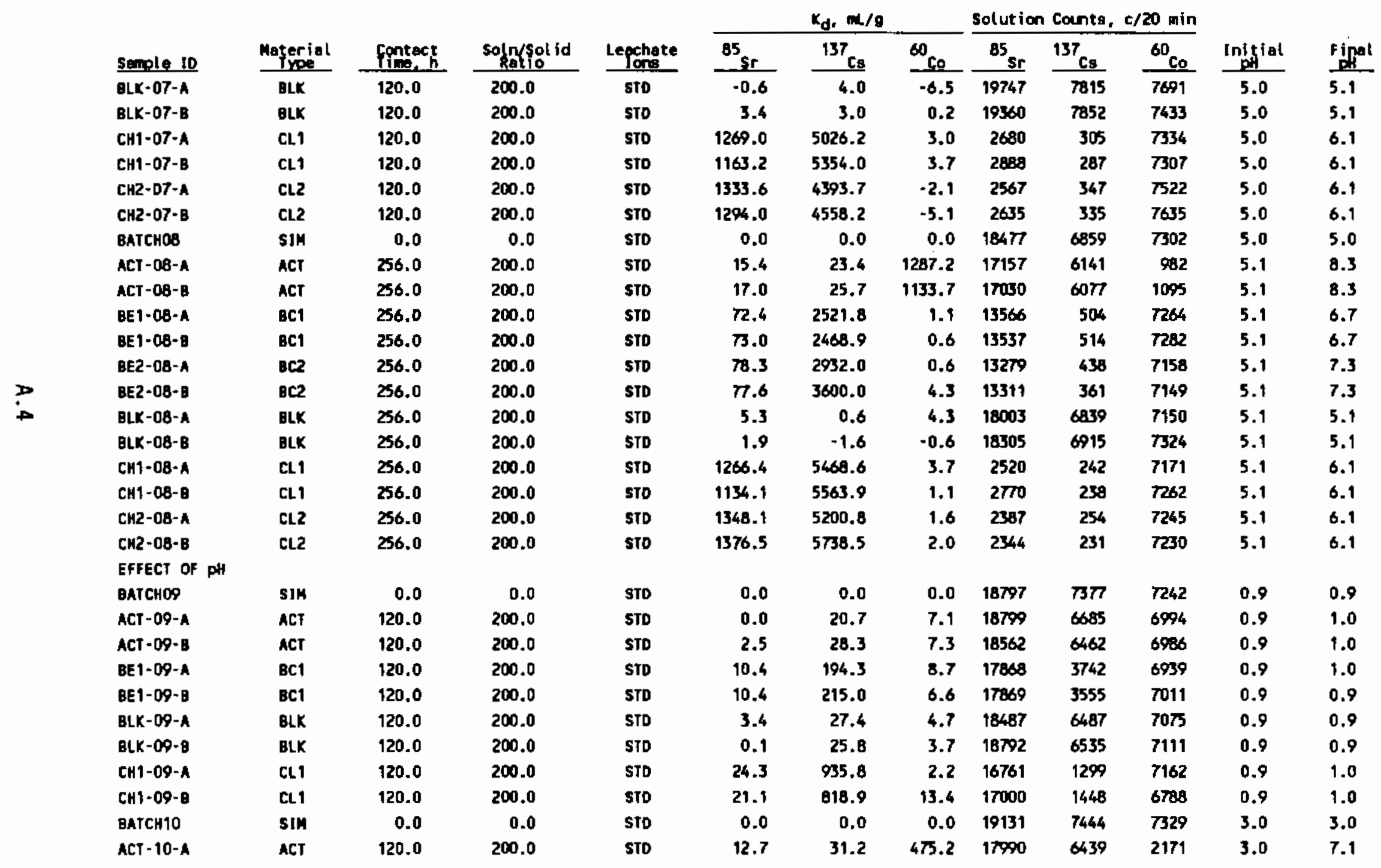


Appendix (contd)

\begin{tabular}{|c|c|c|c|c|c|c|c|c|c|c|c|c|}
\hline \multirow[b]{2}{*}{ Senple ID } & \multirow[b]{2}{*}{ Material } & \multirow[b]{2}{*}{ Contact } & \multirow[b]{2}{*}{$\begin{array}{c}\text { Soln } \\
\text { R日:tio }\end{array}$} & \multirow[b]{2}{*}{$\begin{array}{l}\text { Lepchate } \\
\text { Tons } \\
\end{array}$} & \multicolumn{3}{|c|}{$K_{d}, m_{L} / g$} & \multicolumn{3}{|c|}{ Solution Colnts, $c / 20 \mathrm{~min}$} & \multirow[b]{2}{*}{ Initiol } & \multirow[b]{2}{*}{ Fipal } \\
\hline & & & & & ${ }^{85} 5 r$ & ${ }^{137} \mathrm{Cs}$ & ${ }^{60} \mathrm{Co}$ & ${ }^{85} \mathrm{sr}$ & ${ }^{137} \mathrm{Cs}_{8}$ & ${ }^{60} \mathrm{CO}$ & & \\
\hline ACT-10-9 & ACT & 120.0 & 200.0 & STO & 10.8 & 38.3 & 510.9 & 18152 & 6249 & 2062 & 3.0 & 7.2 \\
\hline$B E 1-10-A$ & ec1 & 120.0 & 200.0 & \$TO & 62.1 & 1876.4 & 3.1 & 14599 & 717 & 7219 & 3.0 & 4.5 \\
\hline BE1-10-8 & BC1 & 120.0 & 200.0 & STO & 65.3 & 2137.2 & -1.4 & 14420 & 637 & 7582 & 3.0 & 4.7 \\
\hline$B L K-10-A$ & BLK & 120.0 & 200.0 & STO & -0.5 & 3.0 & -1.5 & 19182 & 7334 & 7385 & 3.0 & 2.9 \\
\hline BLK $-10-B$ & BLK & 120.0 & 200.0 & STD & -4.9 & 2.0 & -0.1 & 19615 & 7370 & 7334 & 3.0 & 2.9 \\
\hline CH1-10-A & CL.1 & 120.0 & 200.0 & STO & 1144.9 & 1423.6 & 0.4 & 2845 & 917 & 7313 & 3.0 & 3.4 \\
\hline CH1-10-B & CL1 & 120.0 & 200.0 & STO & 1097.9 & 4762.7 & 0.6 & 2948 & 300 & 7309 & 3.0 & 3.4 \\
\hline вАтсн11 & sjm & 0.0 & 0.0 & STO & 0.0 & 0.0 & 0.0 & 19226 & 7600 & 737 & 7.1 & 7.1 \\
\hline АСТ - 11-A & ACT & 120.0 & 200.0 & STO & 17.0 & 20.4 & 1059.3 & 17720 & 6897 & 1171 & 7.1 & 8.6 \\
\hline ACT-11-B & $A C T$ & 120.0 & 200.0 & $5 T 0$ & 19.2 & 25.5 & 1029.9 & 17546 & 6742 & 1199 & 7.1 & 8.6 \\
\hline BE 1-11-A & BC1 & 120.0 & 200.0 & sto & 74.5 & 2462.0 & -0.2 & 14006 & 571 & 7382 & 7.1 & 6.9 \\
\hline BE1-11-B & Bct & 120.0 & 200.0 & STO & 70.8 & 2528.9 & 3.2 & 14199 & 557 & 7256 & 7.1 & 6.9 \\
\hline BLK-11-A & BLK & 120.0 & 200.0 & STO & -0.2 & 14.8 & -7.8 & 19240 & 7075 & 7673 & 7.1 & 6.9 \\
\hline$B L K-11-B$ & BLK & 120.0 & 200.0 & STD & 0.8 & 16.6 & -0.4 & 19148 & 7017 & 7388 & 7.1 & 6.8 \\
\hline CH1-11-A & CL1 & 120.0 & 200.0 & STD & 1211.6 & 4671.8 & -1.1 & 2724 & 312 & 7415 & 7.1 & 6.4 \\
\hline CH1-11-B & CL1 & 120.0 & 200.0 & STD & 1168.4 & 4783.6 & 3.9 & 2810 & 305 & 7231 & 7.1 & 6.5 \\
\hline ВАТСН12 & sik & 0.0 & 0.0 & sto & 0.0 & 0.0 & 0.0 & 16948 & 7145 & 7199 & 9.1 & 9.1 \\
\hline$A C T-12-A$ & ACT & 120.0 & 200.0 & STD & 19.6 & 41.5 & 1106.5 & 15433 & 5917 & 1102 & 9.1 & 8.9 \\
\hline ACT-12-B & ACT & 120.0 & 200.0 & STD & 21.2 & 29.8 & 1195.2 & 15322 & 6218 & 1032 & 9.1 & 8.9 \\
\hline BE1-12-A & BC1 & 120.0 & 200.0 & STD & 78.2 & 277.1 & 0.1 & 12185 & 480 & 7197 & 9.1 & 7.4 \\
\hline BE1-12-B & $\mathrm{BC1}$ & 120.0 & 200.0 & STO & 86.0 & 3560.5 & 12.6 & 11851 & 380 & $67 T 2$ & 9.1 & 7.4 \\
\hline$B L K-12-A$ & BLK & 120.0 & 200.0 & STD & 7.9 & 11.4 & 1.6 & 16301 & 6761 & 7142 & 9.1 & 8.7 \\
\hline$B L K-12-B$ & BLK & 120.0 & 200.0 & STD & B.7 & 45.7 & 5.3 & 16245 & 6624 & 7013 & 9.1 & 8.7 \\
\hline CH1-12-A & CLI & 120.0 & 200.0 & $5 T 0$ & $8 \notin 3.3$ & 6179.5 & 8.1 & 3129 & 224 & 6920 & 9.1 & 7.3 \\
\hline СН1-12-B & CLI & 120.0 & 200.0 & $5 T 0$ & 1064.3 & 5015.3 & 2.7 & 2681 & 274 & 7102 & 9.1 & 7.5 \\
\hline ВАТСН 13 & SIM & 0.0 & 0.0 & STO & 0.0 & 0.0 & 0.0 & 17363 & 6990 & 7194 & 4.9 & 4.9 \\
\hline$A C T-13-A$ & ACT & 120.0 & 20.0 & sto & 14.5 & 10.0 & 1756.3 & 10063 & 4656 & Q1 & 4.9 & 7.0 \\
\hline$A C T-13-B$ & ACT & 120.0 & 20.0 & STD & 16.5 & 7.2 & 1510.6 & 9518 & 5148 & 94 & 4.9 & 7.0 \\
\hline BE1-13-A & BC1 & 120.0 & 20.0 & STO & 91.7 & 1378.0 & 0.1 & 3108 & 100 & 7171 & 4.9 & 8.5 \\
\hline BE1-13-B & BC1 & 120.0 & 20.0 & STO & 93.5 & 1154.8 & 0.3 & 3059 & 119 & 7073 & 4.9 & 8.7 \\
\hline CH1-13-A & $C_{L} 1$ & 120,0 & 20.0 & STO & 723.6 & 3019.1 & -0.3 & 467 & 46 & 7287 & 4.9 & 6.5 \\
\hline
\end{tabular}


Appendix (contd)

\begin{tabular}{|c|c|c|c|c|c|c|c|c|c|c|c|c|}
\hline & & & & & & $\mathbf{K}_{\mathrm{d}}, \mathrm{mL}$ & & Solut io & Counts, & $20 \min$ & & \\
\hline Senple ID & 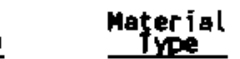 & $\begin{array}{l}\text { fontact } \\
\text { fine, h }\end{array}$ & $\begin{array}{c}\text { Soln/sol id } \\
\text { Ratio }\end{array}$ & $\begin{array}{l}\text { Leachate } \\
\text { lons }\end{array}$ & ${ }^{85} \mathrm{sr}$ & ${ }^{137} \mathrm{Cs}$ & ${ }^{60} \mathrm{Co}$ & ${ }^{85} \mathrm{Sr}$ & ${ }^{137} \mathrm{cs}$ & ${ }^{60} \mathrm{CO}_{\mathrm{O}}$ & Initial & Fingl \\
\hline CH1-13-B & cLl & 120.0 & 20.0 & STO & 472.6 & 2617.7 & -0.2 & 705 & 53 & 7276 & 4.9 & 6.4 \\
\hline BATCH14 & SIM & 0.0 & 0.0 & STD & 0.0 & 0.0 & 0.0 & 17137 & 7197 & $\pi 18$ & 4.9 & 4.9 \\
\hline$A C T-14-A$ & ACT & 120.0 & 8.0 & STO & 35.4 & 6.5 & 2607.0 & 3158 & 3980 & 23 & 4.9 & B.5 \\
\hline ACT $-14-B$ & ACT & 120.0 & 8.0 & STD & 32.0 & 6.2 & 1760.9 & 3432 & 4043 & 34 & 4.9 & 8.5 \\
\hline$C H 1-14-A$ & CLI & 120.0 & 8.0 & STD & 289.4 & 2206.5 & 0.5 & 461 & 26 & 2079 & 4.9 & 6.6 \\
\hline $\mathrm{CH} 1-14-\mathrm{B}$ & cL1 & 120.0 & 8.0 & STD & 353.7 & 1191.5 & 0.6 & 379 & 48 & 7008 & 4.9 & 6.6 \\
\hline EFFECT OF & PARTICLE SIZE & & & & & & & & & & & \\
\hline BATCH15 & S1M & .0 & 0.0 & STD & 0.0 & 0.0 & 0.0 & 19377 & 7920 & 7174 & 5.0 & 5.0 \\
\hline AG1.0-15A & $A C$ & 4.0 & 20.0 & STO & 22.6 & 38.2 & 962.7 & 17411 & 6650 & 1234 & 5.0 & 9.3 \\
\hline AG1,0-15B & ACO & 4.0 & 200.0 & STO & 24.0 & 46.2 & 982.9 & 17300 & 6434 & 1213 & 5.0 & 9.3 \\
\hline CG1.0.15A & CLG & 4.0 & 200.0 & STD & 399.5 & 7201.9 & 10.4 & 6464 & 214 & 6820 & 5.0 & 6.3 \\
\hline CG1.0.158 & CLG & 4.0 & 200.0 & STD & 389.2 & 7099.5 & 8.2 & 6578 & 217 & 6892 & 5.0 & 6.3 \\
\hline BATCH16 & sin & 0.0 & 0.0 & STD & 0.0 & 0.0 & 0.0 & 19028 & 7297 & 6898 & 5.1 & 5.1 \\
\hline AC1.0-16A & ACT & 16.0 & 200.0 & Std & 10.7 & 12.0 & 588.8 & 18058 & 6885 & 1749 & 5.1 & 9.2 \\
\hline$A C 0.6-16 A$ & ACT & 16.0 & 333.3 & std & 10.2 & 33.0 & $4 \pi .7$ & 18464 & 6640 & 2835 & 5.1 & 9.0 \\
\hline$A C O .2-16 A$ & ACT & 16.0 & 1000.0 & std & 8.3 & 81.8 & 37.7 & 18872 & 6745 & 5007 & 5.1 & 0.4 \\
\hline$A G 1.0-16 A$ & ACG & 16.0 & 200.0 & Std & 24.9 & 41.5 & 911.7 & 16925 & 6042 & 1241 & 5.1 & 9.3 \\
\hline$A G 0.6-16 A$ & ACG & 16.0 & 333.3 & std & 20.8 & 49.5 & 793.8 & 17911 & 6354 & 2040 & 5.1 & 9.1 \\
\hline$A G 0.2-16 A$ & ACG & 16.0 & 1000.0 & std & 17.7 & 144.8 & 715.9 & 18698 & 6374 & 4020 & 5.1 & 8.5 \\
\hline CH1.0-16A & CLI & 16.0 & 200.0 & std & 721.5 & $\mathbf{3 3 2 5 . 1}$ & 3.2 & 4130 & 414 & 6788 & 5.1 & 6.0 \\
\hline CHO.6-16A & CL1 & 16.0 & 333.3 & std & 660.0 & 3217.5 & -1.6 & 6385 & 685 & 6932 & 5.1 & 5.8 \\
\hline CHO.2-16A & CL1 & 16.0 & 1000.0 & std & 638.2 & 4029.0 & -11.3 & 11615 & 1451 & 6977 & 5.1 & 5.7 \\
\hline CG1.0-1GA & CLG & 16.0 & 200.0 & Std & 834.8 & 4902.8 & 1.3 & 3508 & 286 & 6853 & 5.1 & 6.3 \\
\hline CG0.6-16A & CLG & 16.0 & 333.3 & std & 737.6 & 5120.3 & .7 .9 & 5814 & 446 & 7065 & 5.1 & 6.2 \\
\hline CGO.2-16A & CLG & 16.0 & 1000.0 & std & 991.4 & 8403.4 & -6.3 & 9555 & 776 & 6942 & 5.1 & 5.8 \\
\hline BATCH17 & sin & 0.0 & 0.0 & std & 0.0 & 0.0 & 0.0 & 18800 & 6502 & 6749 & 5.0 & 5.0 \\
\hline AC1,0-17A & $\mathrm{ACr}$ & 120.0 & 200.0 & std & 19.9 & 20.1 & 1997.3 & 17100 & 5908 & 906 & 5.0 & 8.5 \\
\hline$A C 0.6-17 \AA$ & ACr & 120.0 & 333.3 & Std & 20.3 & 20.2 & 878.1 & $1 \mathrm{~m} 23$ & 6130 & 1857 & 5.0 & 8.2 \\
\hline$A C 0.2-17 \AA$ & ACT & 120.0 & 1000.0 & std & 24.1 & -43.5 & 729.2 & 18357 & 6798 & 3903 & 5.0 & 7.8 \\
\hline$A G 1.0-17 A$ & ACG & 120.0 & 200.0 & Std & 29.8 & 43.1 & 1180.2 & 16365 & 5349 & 978 & 5.0 & 8.7 \\
\hline$A G 0.6-17 \AA$ & ACG & 120.0 & 333.3 & std & 32.8 & 25.6 & 1043.5 & 17118 & 6030 & 1634 & 5.0 & 8.6 \\
\hline
\end{tabular}


Appendix (contd)

\begin{tabular}{|c|c|c|c|c|c|c|c|c|c|c|c|c|}
\hline \multirow[b]{2}{*}{ Semple ID } & \multirow[b]{2}{*}{$\begin{array}{c}\text { Mețerial } \\
\text { type } \\
\end{array}$} & \multirow[b]{2}{*}{ fontact } & \multirow[b]{2}{*}{ Soln/sol id } & \multirow[b]{2}{*}{$\begin{array}{l}\text { Lepchate } \\
\text { lons }\end{array}$} & \multicolumn{3}{|c|}{$K_{d}, m L / g$} & \multicolumn{2}{|c|}{ Solut ion Counts, } & \multirow{2}{*}{$\frac{c / 20 \mathrm{~min}}{{ }^{60} \mathrm{Co}}$} & \multirow[b]{2}{*}{ Initial } & \multirow[b]{2}{*}{ Final } \\
\hline & & & & & ${ }^{85} \mathrm{Sr}$ & ${ }^{137} \mathrm{Cs}_{\mathrm{s}}$ & ${ }_{\mathrm{CO}}$ & ${ }^{85} \mathrm{Sr}$ & ${ }^{137_{\mathrm{Cs}}}$ & & & \\
\hline$\overline{A G 0.2-17 A}$ & ACO & 120.0 & 1000.0 & Std & 51.0 & $\overline{15.0}$ & 923.3 & 17887 & 6601 & 3509 & 5.0 & 8.2 \\
\hline CH1.0-17h & CLI & 120.0 & 200.0 & std & 1316.7 & 5429.4 & 17.7 & 2479 & 231 & 6201 & 5.0 & 6.1 \\
\hline СНо.6-17A & $\mathrm{CLI}$ & 120.0 & 333.3 & std & 1472.1 & 4839.3 & 14.1 & 3471 & 419 & 6476 & 5.0 & 6.1 \\
\hline CHO.2-17A & $\mathrm{CL} 1$ & 120.0 & 1000.0 & std & 1614.4 & 5917.0 & -0.2 & 7191 & 940 & 6750 & 5.0 & 6.2 \\
\hline $\cos .0-17 a$ & CLa & 120.0 & 200.0 & Std & 1313.1 & 6644.2 & 10.4 & 2485 & 190 & 6415 & 5.0 & 6.7 \\
\hline $\operatorname{cco} .6-17 A$ & CLG & 120.0 & 333.3 & std & 1424.5 & 5209.7 & 11.9 & 3565 & 391 & 6517 & 5.0 & 6.2 \\
\hline $\operatorname{ces} .2-17 A$ & CLG & 120.0 & 1000.0 & std & 1654.2 & 7240.8 & 10.8 & 7083 & 789 & 6677 & 5.0 & 6.1 \\
\hline BAtch19 & sim & 0.0 & 0.0 & NRI & 0.0 & 0.0 & 0.0 & 20718 & 7958 & rors & 5.0 & 5.0 \\
\hline$A C-05-19 A$ & ACT & 1.0 & 40.0 & NR! & 5.0 & 64.1 & 48.2 & 18426 & 3057 & 3208 & 5.0 & 6.6 \\
\hline$A C=05-198$ & ACT & 1.0 & 40.0 & NRI & 5.5 & 62.3 & 48.4 & 18223 & 3111 & 3199 & 5.0 & 6.6 \\
\hline$A C-02-19 A$ & ACT & 1.0 & 100.0 & MRJ & 7.0 & 103.8 & 45.4 & 19360 & 3905 & 4865 & 5.0 & 6.2 \\
\hline$A C-02-198$ & ACT & 1.0 & 100.0 & NRI & 6.5 & 90.3 & 41.4 & 19455 & 4183 & 5003 & 5.0 & 6.2 \\
\hline$B L K-19 A$ & BLK & 1.0 & 0.0 & NRI & 0.0 & 0.0 & 0.0 & 17991 & 1031 & 3985 & 5.0 & 5.2 \\
\hline BLK-19B & BLK & 1.0 & 0.0 & NRI & 0.0 & 0.0 & 0.0 & 17758 & 968 & $41 t 3$ & 5.0 & 5.0 \\
\hline СH-05-19A & CL1 & 1.0 & 40.0 & MRI & 23.3 & 608.9 & 13.0 & 13095 & 375 & 5336 & 5.0 & 5.2 \\
\hline CH- $05-193$ & CL1 & 1.0 & 40.0 & WR I & 25.0 & 802.1 & 12.9 & 12756 & 378 & 5351 & 5.0 & 5.2 \\
\hline CH-02-19A & CL1 & 1.0 & 100.0 & NRI & 31.8 & 1196.1 & 27.0 & 15714 & 614 & 5568 & 5.0 & 5.1 \\
\hline CH- OL-193 & CLI & 1.0 & 100.0 & NR! & 28.2 & 1055.0 & 26.5 & 16156 & 689 & 5592 & 5.0 & 5.1 \\
\hline$A C-01-19 A$ & CL1 & 1.0 & 200.0 & MRI & 7.2 & 149.3 & 62.8 & 19995 & 4557 & 5382 & 5.0 & 6.0 \\
\hline $\mathrm{CH}-01-19 \mathrm{~A}$ & CL1 & 1.0 & 200.0 & MR 1 & 37.7 & 1326.0 & 49.1 & 17433 & 1043 & 5679 & 5.0 & 5.2 \\
\hline & \multicolumn{12}{|c|}{ SAVANHAH RIVER SOIL TESTS } \\
\hline ватснго & $\sin$ & .0 & 0.0 & con & 0.0 & 0.0 & 0.0 & 20820 & 12876 & 8893 & 5.1 & 5.1 \\
\hline $\mathrm{A} 120 \mathrm{H}-2 \mathrm{OA}$ & ACT & .0 & 200.0 & $\cos$ & 3.2 & 15.9 & 69.8 & 20488 & 11928 & 6592 & 5.1 & 6.3 \\
\hline A120H-208 & ACT & 120.0 & 20.0 & $\operatorname{con}$ & 7.8 & 14.9 & 71.4 & 20040 & 11982 & 6553 & 5.1 & 6.3 \\
\hline $\mathrm{C} 12 \mathrm{OH}-2 \mathrm{OA}$ & CLI & 120.0 & 200.0 & $\operatorname{con}$ & 478.8 & 1029.8 & 2.1 & 6134 & 2094 & 8802 & 5.1 & 5.5 \\
\hline $\mathrm{C} 120 \mathrm{H}-20 \mathrm{O}$ & CL1 & 120.0 & 200.0 & $\operatorname{con}$ & 468.1 & 1073.6 & 2.9 & 6233 & 2022 & 8764 & 5.1 & 5.3 \\
\hline BLK-20A & sRs & 120.0 & 0.0 & $\cos$ & 2.5 & 2.0 & -3.3 & 20561 & 12749 & 9044 & 5.1 & 5.0 \\
\hline BLK-209 & SRS & 120.0 & 0.0 & $\operatorname{com}$ & 2.4 & 1.3 & -3.5 & 20575 & 12793 & 9050 & 5.1 & 5.0 \\
\hline $5100-20 A$ & SRS & 120.0 & 20.0 & $\mathrm{com}$ & 0.6 & 65.2 & 2.9 & 20229 & 3021 & 753 & 5.1 & 4.0 \\
\hline \$106-20B & SRS & 120.0 & 20.0 & $\cos$ & 0.8 & 62.7 & 3.4 & 20065 & 3115 & 7617 & 5.1 & 4.0 \\
\hline $550-20 k$ & SRS & 120.0 & 40.0 & $\cos$ & 0.6 & 105.9 & 3.1 & 20497 & 3530 & B258 & 5.1 & 4.1 \\
\hline
\end{tabular}


Appendix (contd)

\begin{tabular}{|c|c|c|c|c|c|c|c|c|c|c|c|c|}
\hline \multirow[b]{2}{*}{ Semple 10 } & \multirow[b]{2}{*}{$\begin{array}{l}\text { Material } \\
\text { tye } \\
\end{array}$} & \multirow[b]{2}{*}{$\begin{array}{l}\text { Gontact } \\
\text { fille, h } \\
\end{array}$} & \multirow[b]{2}{*}{$\begin{array}{l}\text { Soln/sol id } \\
\text { Ratio }\end{array}$} & \multirow[b]{2}{*}{$\begin{array}{c}\text { Lepchote } \\
\text { Ions }\end{array}$} & \multicolumn{3}{|c|}{$K_{d,}$, aL/B } & \multicolumn{3}{|c|}{ Solution Counts, $c / 20$ min } & \multirow[b]{2}{*}{ Initial } & \multirow[b]{2}{*}{ Finel } \\
\hline & & & & & ${ }^{85} \mathrm{Sr}$ & ${ }^{137} \mathrm{Cs}$ & ${ }^{60} \mathrm{Co}_{0}$ & ${ }^{85} \mathrm{Sr}$ & ${ }^{137} \mathrm{Cs}$ & ${ }^{60} \mathrm{Co}$ & & \\
\hline 556.209 & SRS & 120.0 & 40.0 & $\infty$ & 0.6 & 114.7 & 3.6 & 20523 & 3330 & 8156 & 5.1 & 4.1 \\
\hline SIP-20A & SRS & 120.0 & 200.0 & con & 20.6 & 54.6 & 19.2 & 18878 & 10113 & 8113 & 1.0 & 1.0 \\
\hline S1P.20B & SRS & 120.0 & 200.0 & $\infty$ & 22.0 & 48.2 & 23.8 & 18754 & 10377 & 7946 & 1.0 & 1.0 \\
\hline$\$ 3 P-204$ & SRS & 120.0 & 200.0 & $\cos$ & -2.6 & $\pi .1$ & 2.3 & 21091 & $92 \%$ & 8703 & 3.0 & 3.0 \\
\hline $53 P-208$ & SRS & 120.0 & 200.0 & $\infty$ & -1.5 & 192.3 & -2.2 & 20982 & 6565 & 891 & 3.0 & 3.0 \\
\hline$\$ 5 p-20$ & SRS & 120.0 & 200.0 & cor & -0.2 & 259.5 & -3.7 & 20844 & 5604 & 9061 & 5.1 & 4.3 \\
\hline S5P-208 & SRS & 120.0 & 200.0 & $\infty$ & 1.2 & 284.2 & -2.3 & 20701 & 5318 & 8995 & 5.1 & 4.3 \\
\hline $5.50-20 \mathrm{~A}$ & SRS & 120.0 & 400.0 & cons & -2.4 & 403.2 & -2.1 & 20943 & 6412 & $8 \% 40$ & 5.1 & 4.5 \\
\hline $5.50-20 B$ & SRS & 120.0 & 400.0 & $\infty$ & 3.8 & 384.6 & -6.0 & 20626 & 6482 & 9029 & 5.1 & 4.5 \\
\hline BATCH21A7 & SIM & 0.0 & 0.0 & STO & 0.0 & 0.0 & 0.0 & 20870 & 13097 & 8370 & 7.0 & 7.0 \\
\hline BATCHZ1A9 & sin & 0.0 & 0.0 & STO & 0.0 & 0.0 & 0.0 & 20771 & 12928 & 8988 & 9.0 & 9.0 \\
\hline $57 \mathrm{P}-21 \mathrm{~h}$ & SRs & 120.0 & 200.0 & STD & 7.9 & 625.5 & -3.8 & 20079 & 3173 & 9041 & 7.0 & 5.3 \\
\hline s7P-21B & SRS & 120.0 & 200.0 & STo & 5.6 & 545.4 & -0.3 & 20300 & 3514 & 8884 & 7.0 & 5.5 \\
\hline$s 9 p-21 A$ & sas & 120.0 & 200.0 & STo & 9.6 & 646.9 & 1.0 & 19919 & 3093 & 8827 & 9.0 & 5.0 \\
\hline $59 p-21 B$ & SRS & 120.0 & 200.0 & STO & 2.4 & 047.4 & -3.5 & 20622 & 3081 & 9027 & 9.0 & 5.9 \\
\hline
\end{tabular}

$A C T=$ Activated Carbon

$\mathrm{BC1}=$ Granulor Bentanite $\mathrm{Clay}$

BC2 = Poudered Bentonite Clay

CL1 = -5 mesh CH Clinoptilalite

CL2 $=-5+35$ CH mesh Clinoptilolite

CL3 $=-5$ mesh XY Clínoptilolite

CL4 $=-5+35$ mesh XY Cl inoptilolite

SRS = Sovannah River Soil

SIH = Simulated Leachate

STD = Standard Composition

RI = Nonradioactive model ions

CON = Combination redioactíve $\&$ model ions 


\section{DISTRIBUTION}

No. of

Copies

OFFSITE

10 DOE/Office of Scientific and Technical Information

6 DOE Office of Defense Waste \& Transportation Management GTN

Washington, DC 20545

ATTN: T. C. Chee, DP-123

S. P. Cowan, DP-12

C. H. George, OP-123

T. B. Hindman, DP-12

E. A. Jordan, DP-122

L. C. Waldo, DP-122

3 DOE Office of Remedial Action and GTN Waste Technology

Washington, DC 20545

ATTN: J. A. Coleman, NE-24

T. W. McIntosh, NE-24

H. F. Walter, NE-24

A. T. Clark

Division of Fuel Material Safety

Nuclear Regulatory Commission

Washington, DC 20555

J. Starmer

U.S. Nuclear Regulatory Commission 55111 Rockville Pike Rockville, MD 20852

Environmental Protection Agency Office of Radiation Programs (ANR-428) 40I M Street, S.W.

Washington, DC 20460

P. A. Saxman

DOE A1buquerque Operations Office

P.0. Box 5400

Albuquerque, NM 87185
No. of

Copies
E. Maestas

DOE West Valley Operations Office

P.0. Box 191

West Valley, NY 14171

M. W. Shupe

DOE ldaho Operations Office

550 Second Street

Idaho Falls, ID 83401

F. T. Fong

DOE San Francisco Operations

1333 Broadway

0akl and, CA 94612

M. R. Jugan

DOE Oak Ridge Operations

Office

P.O BoX E

Oak Ridge, TN 37830

W. D. Pearson

DOE Savannah River Operations Office

P.0. Box A

Aiken, SC 29801

M. J. Steindler

Argonne National Laboratory

9700 South Cass Avenue

Argonne, IL 60439

C. S. Abrams

Argonne National Laboratory

P.0. Box 2528

Idaho Falls, ID 83401

D. T. Oakley, MS 619

Los Alamos Scientific

Laboratory

P.0. Box 1663

Los Alamos, NM 87544 
No. of

Copies

4 Oak Ridge Nationa] Laboratory

P.0. Box Y

Oak Ridge, TN 37830

ATTN: R. Clap

C. Fore

R. T. Jubin

L. J. Mezga

4 Sandia Laboratories

P.0. Box 5800

Aibuquerque, NM 87185

ATTN: D. R. Anderson

R. W. Lynch

W. Weart

Technical Library

J. R. Berreth

Westinghouse Idaho Nuclear Co., Inc.

P.0. Box 4000

Idaho Falls, ID 83401

3 E. I. Du Pont de Nemours Company

Savannah River Laboratory

Aiken, SC 29801

ATTN: C. M. King

J. Stone

H. F. Sturm, Jr.

23 EG\&G Idaho

P.0. Box 1625

Idaho FaTls, 1083401

ATTN: J. Bradford (20)

J. MeConnel1

A. D. Rogers

R. Shilkett

R. A. Shaw

Electric Power Research Institute 3412 Hillview Avenue

P.0. Box 10412

Palo Alto, CA 94304
No. of

Copies

4 West Valley Nuclear Services Co. P.0. Box 191

West Valley, NY 14171

ATTN: S. M. Barnes

J. J. Buggy

J. M. Pope

R. A. Thomas

C. Hornibrook

Energy Research \& Development Authority

Empire State Plaza

ALbany, NY 12223

4 Brookhaven National Laboratory

Nuclear Waste Management Division Upton, NY 11973

ATTN: P. Colombo

M. Fuhrman

C. R. Kempf

T. Sullivan

A. Pasternak

California Radioactive Materials Management Forum

455 Capitol Mall

Suite 380

Sacramento, CA 95814

L. D. Ramspott

Lawrence Livermore National

Laboratory

University of California

P.0. Box 808

Livermore, CA 94550

\section{ONSITE}

6 DOE Richland 0perations office

E. A. Bracken

R. J. Nevarez

S. M. Prestwich

G. W. Rosenwald

J. J. Sutey

D. Wanek 
No. of

Copies

4 Westinghouse Hanford Company

H. E. McGuire

K. Owens

D. Postman

D. A. Turner

38 Pacific Northwest Laboratory

L. A. Bray

J. L. Buelt

M. R. Elmore

H. D. Freeman (15)

G. W. Gee

M. S. Hanson
No. of

Copies

J. N. Hart ley

E. 0 . Jones

J. L. McElroy

D. H. Mitchell

S. J. Mitchell

W. A. Ross

R. J. Serne

R. L. Skaggs

S. C. Slate (2)

T. L. Stewart

J. L. Swanson

Publishing Coordination

Technical Report Files (5) 


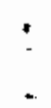

$x$ 